NATIONAL LABORATORY

\title{
Status and Prospects of the Global Automotive Fuel Cell Industry and Plans for Deployment of Fuel Cell Vehicles and Hydrogen Refueling Infrastructure
}

Revised July $2013^{1}$

Prepared by

David L. Greene

Oak Ridge National Laboratory

Gopal Duleep

HD Systems

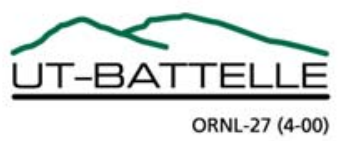

${ }^{1}$ This is a revised version of the paper originally published in June 2013. 


\section{DOCUMENT AVAILABILITY}

Reports produced after January 1, 1996, are generally available free via the U.S. Department of Energy (DOE) Information Bridge.

Web site http://www.osti.gov/bridge

Reports produced before January 1, 1996, may be purchased by members of the public from the following source.

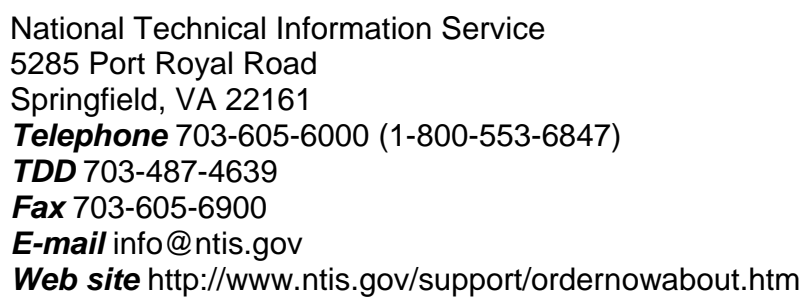

Reports are available to DOE employees, DOE contractors, Energy Technology Data Exchange (ETDE) representatives, and International Nuclear Information System (INIS) representatives from the following source.

Office of Scientific and Technical Information

P.O. Box 62

Oak Ridge, TN 37831

Telephone 865-576-8401

Fax 865-576-5728

E-mail reports@osti.gov

Web site http://www.osti.gov/contact.html

This report was prepared as an account of work sponsored by an agency of the United States Government. Neither the United States Government nor any agency thereof, nor any of their employees, makes any warranty, express or implied, or assumes any legal liability or responsibility for the accuracy, completeness, or usefulness of any information, apparatus, product, or process disclosed, or represents that its use would not infringe privately owned rights. Reference herein to any specific commercial product, process, or service by trade name, trademark, manufacturer, or otherwise, does not necessarily constitute or imply its endorsement, recommendation, or favoring by the United States Government or any agency thereof. The views and opinions of authors expressed herein do not necessarily state or reflect those of the United States Government or any agency thereof. 
ORNL/TM-2013/222

Energy and Transportation Science Division

Center for Transportation Analysis

\title{
STATUS AND PROSPECTS OF THE GLOBAL AUTOMOTIVE FUEL CELL INDUSTRY AND PLANS FOR DEPLOYMENT OF FUEL CELL VEHICLES AND HYDROGEN REFUELING INFRASTRUCTURE
}

\author{
David L. Greene \\ Oak Ridge National Laboratory \\ Gopal Duleep \\ HD Systems \\ Date Published: June 2013 \\ Revision: July 2013

\begin{abstract}
Funded by
U.S. Department of Energy's

Office of Energy Efficiency and Renewable Energy

Fuel Cell Technologies Office
\end{abstract} \\ Prepared by \\ OAK RIDGE NATIONAL LABORATORY \\ Oak Ridge, Tennessee 37831-6283 \\ managed by \\ UT-BATTELLE, LLC \\ for the \\ U.S. DEPARTMENT OF ENERGY \\ under contract DE-AC05-00OR22725
}





\section{CONTENTS}

Page

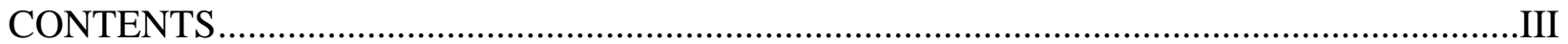

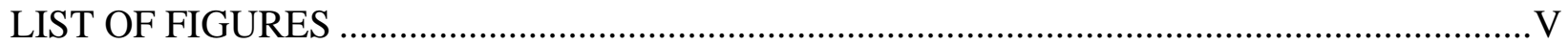

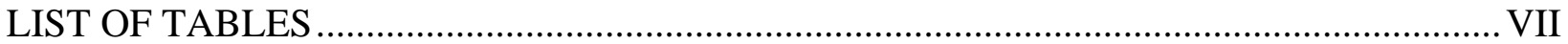

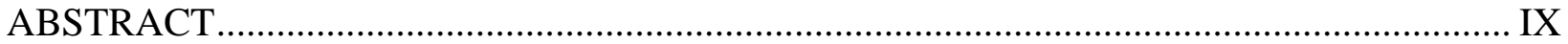

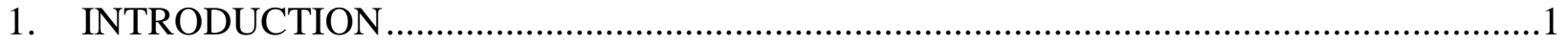

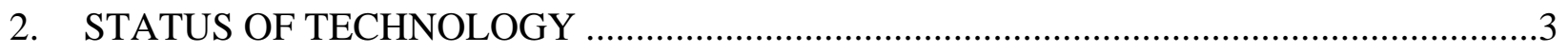

2.1 STACK PERFORMANCE ................................................................................

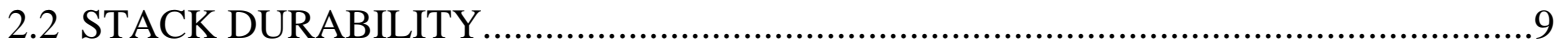

2.3 BALANCE OF PLANT AND HYDROGEN STORAGE TANKS ............................11

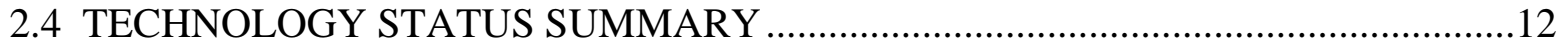

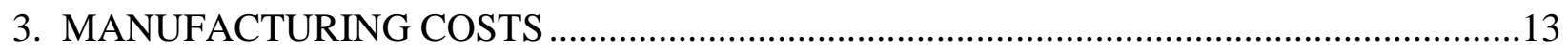

3.1 THE EU GOVERNMENT/INDUSTRY POWERTRAIN STUDY ….........................14

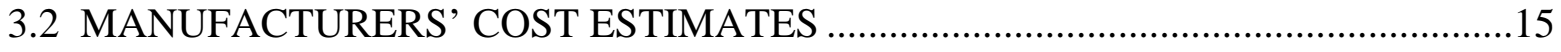

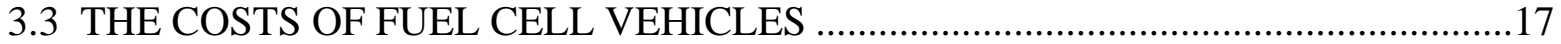

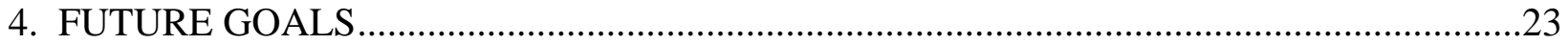

5. FUEL CELL VEHICLE MARKET INTRODUCTION AND INFRASTRUCTURE

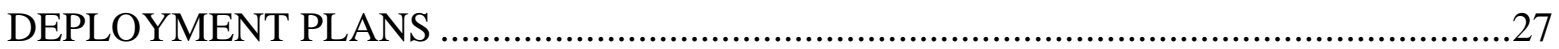

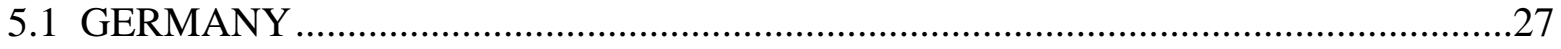

5.2 JAPAN

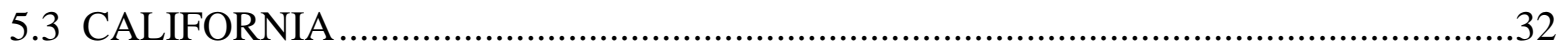

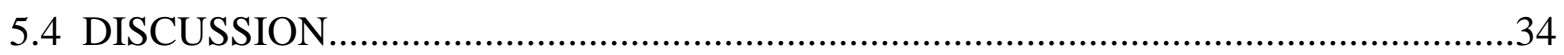

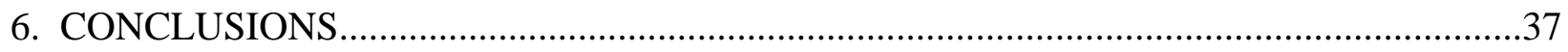

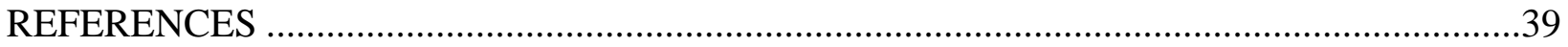




\section{LIST OF FIGURES}

Figure

Page

1 Chinese Organizations Involved in Fuel Cell Research .............................................4

2 Evolution of Honda's Fuel Cell Stack Performance.........................................................5

3 Stack Characteristics from Nissan .....................................................................6

4 Improvements in Stack Technology Responsible For Higher Power Density ...................7

5 Development of GM’s Fuel Cell Performance from 2005 to 2010 .................................8

6 Duty Cycle Effects on Stack Performance Degradation.................................................10

7 Platinum Loading Reduction Anticipated By GM....................................................11

8 BMW Estimates of On-Board Hydrogen Storage Cost ................................................18

9 Cost Estimates for Automotive Fuel Cell Systems at Full Scale and Learning................23

10 FCV Cost as a Function of Scale, Technological Improvement and Learning By

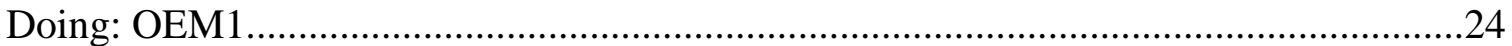

11 FCV Cost as a Function of Scale, Technological Improvement and Learning By

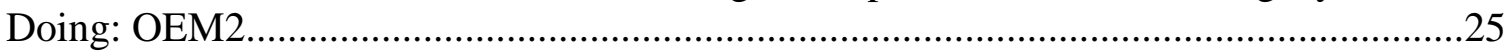

12 FCV Cost as a Function of Scale, Technological Improvement and Learning By

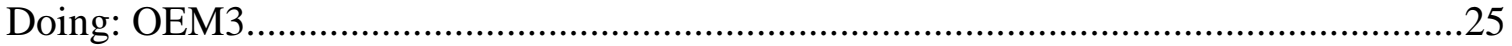

13 Potential Hydrogen Refueling Station Rollout in Germany .........................................29

14 Existing And Planned Clusters of Hydrogen Stations in Southern California ...................34 


\section{LIST OF TABLES}

Table

Page

1 McKinsey Study Cost Estimates for 85 kW Stack .....................................................14

2 McKinsey 2020 Cost and Estimated 2015 Costs for a Midsize FCV ...............................15

3 ANL Estimates of Hydrogen Storage Tank Cost at High Production Volumes................19

4 Central Tendency Estimates of FCV Cost at 20K/yr Production Volume

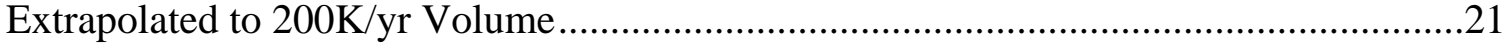

5 Estimates of FCV Cost at 200K/yr Production Volume for 2016 and 2020+ .................22

6 CAFCP Estimates of Hydrogen Fuel Cell Vehicle Sales in California

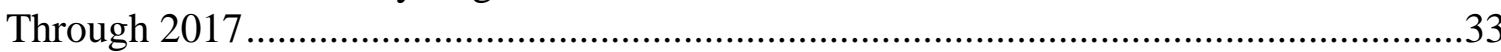

7 Comparison of CAFCP Station Deployments and Anticipated FCV Sales with

Estimated Minimum ZEV FCV Requirements. .33 


\begin{abstract}
Automobile manufacturers leading the development of mass-market fuel cell vehicles (FCVs) were interviewed in Japan, Korea, Germany and the United States. There is general agreement that the performance of FCVs with respect to durability, cold start, packaging, acceleration, refueling time and range has progressed to the point where vehicles that could be brought to market in 2015 will satisfy customer expectations. However, cost and the lack of refueling infrastructure remain significant barriers. Costs have been dramatically reduced over the past decade, yet are still about twice what appears to be needed for sustainable market success. While all four countries have plans for the early deployment of hydrogen refueling infrastructure, the roles of government, industry and the public in creating a viable hydrogen refueling infrastructure remain unresolved. The existence of an adequate refueling infrastructure and supporting government policies are likely to be the critical factors that determine when and where hydrogen FCVs are brought to market.
\end{abstract}




\section{INTRODUCTION}

At least eight of the world's largest automobile manufacturers have plans to bring fuel cell vehicles (FCVs) to market sometime between 2013 and 2020. Governments in the Members of the European Union (EU), United States, Japan and Korea have developed plans to deploy hydrogen refueling infrastructure to support the early market introduction of hydrogen fuel cell vehicles (HFCV). This study assesses the current status of automotive fuel cell technology and the plans for deploying of refueling infrastructure. Interviews with the leading original equipment manufacturers (OEMs) and with governmental agencies and non-governmental organizations (NGOs) in the United States, Japan, South Korea and Germany were conducted in late summer and fall of 2012. The information obtained was combined with data from the open literature and public meetings, and analyzed with the objective of providing a comprehensive view of the current status of the industry and its future prospects.

The status of automotive fuel cell technology is reviewed in Section 2. Fuel cell technology has progressed to the point where the leading manufacturers are convinced they can bring FCVs to the market that will satisfy their customers' expectations for performance and durability. However, costs remain too high for success in the mass market. The reasons for this and generalized FCV manufacturing cost estimates are presented in Section 3. Section 4 compares progress in automotive fuel cell manufacturing costs to date with the future cost reductions believed necessary to compete effectively with internal combustion engine vehicles, and estimates scale economies, rates of learning and rates of technological progress that would be sufficient to achieve future goals. Section 5 considers current plans for deploying hydrogen refueling infrastructure, a critical pre-condition for developing FCV market. Together with cost reduction, the development of an adequate hydrogen refueling infrastructure is now OEMs' greatest concern. Refueling infrastructure will be the key factor in OEMs' decisions about when and where to introduce mass-produced HFCVs.

With the exception of previously published, publicly available documents, the information presented in this report is not attributed to any specific OEM or other industry source. While this will reduce the usefulness of the report to some, maintaining OEM anonymity is an essential enabler of the candid and frank discussions that inform this report. Instead, we attempt to report consensus views or, where consensus is lacking to note the differences of opinion without attribution. Individuals interviewed were offered the opportunity to review and correct summaries of their interviews and we have attempted to make all the corrections requested. However, the authors alone are responsible for any errors or misinterpretations that remain. 


\section{STATUS OF TECHNOLOGY}

FCV related research and development has been pursued by most major auto manufacturers for over 25 years but the focus of development has shifted. In the 1990s, the development of the stack was typically outsourced to companies such as Ballard and UTC with the OEMs focusing on vehicle integration. In the 2000 to 2010 time frame, auto manufacturers came to the conclusion that stack development and manufacture would be a core competency in the future and therefore pulled most of the stack development into the company, while sourcing stack components from suppliers. Some manufacturers concluded that FCV introduction would not be feasible until the 2020-2030 decade and thus de-emphasized vehicle development in favor of the battery-electric or plug-in hybrid vehicles. At present, all significant FCV development activities appear to be concentrated in the United States, Germany, Japan and Korea with some modest developments in China.

In the United States, Chrysler has not been publicly identified with any ongoing research and development (R\&D) on fuel cells since its separation from Daimler. Ford initially was part of a three way partenrship with Daimler and Ballard to develop fuel cells, but Daimler has taken control of this partnership which is now called Nucellsys, based in Germany. Ford later entered into an agreement with Daimler and Ballard called Automtoive Fuel Cell Cooperation (AFCC) that works closely with Nucellsys. AFCC appears to be more focused on product design and development, while Nucellsys is more focused on R\&D. Just this year, Ford joined a new cooperative agreement with Daimler, and Renault-Nissan to jointly develop a common fuel cell system with the goal of producing “...the world's first affordable, mass-market fuel cell electric vehicle as early as 2017” (www.media.blog, 2013). The objective of the alliance is to reduce engineering investment costs, and by maximizing design commonality to increase economies of scale and drive efficiencies throughout the supply chain. General Motors (GM) has been the most active of the domestic corporations in fuel cell R\&D but its focus appears to have shifted over the last two years to plug-in hybrids like the Chevy Volt while fuel cell activities are being reduced. In late-2012, GM closed its fuel cell research centers in Honeye Falls, NY and in Germany and all fuel cell research is now concentrated in Michigan. Although this move is part of a general consolidation of GM's powertrain research at Pontiac, Michigan, it is widely regarded as a setback for fuel cell development at GM (GM, 2013).

In Japan, the three largest auto manufacturers continue to be active in FCV R\&D. Both Toyota and Honda have large FCV development programs. Nissan has historically had a smaller program relative to Toyota and Honda, possibly due to its focus on battery electric vehicles (BEVs) like the Leaf. As noted above, Nissan and Renault have teamed with Daimler and Ford and independent development by Nissan may no longer be neccessary. Toyota has teamed with BMW in a technology sharing agreement for FCVs, and although Toyota has maintained 2015 as its likely date for market introduction of FCVs, the speculation is that BMW is aiming at 2020 (Wall Street Journal (WSJ), 2013). Honda, the first manufacturer to lease FCVs to the public, 
the FCX Clarity in the United States in 2008, is still developing fuel cells vehicles independently at its research center in Tochigi, Japan (Honda, 2013).

Hyundai is potentially the most aggressive promoter of FCVs and has had a development program for over 10 years. While other manufacturers have only hinted at commercial introduction of FCV models in 2015-2016, Hyundai has announced that it will build about 1,000 FCVs by 2015, and will have a commercial model with sales volumes in the 10,000/year beyond 2015 (Hyundai, 2013). Production of the ix35 on an assembly line at the company's Ulsan, South Korea plant began in January 2013 with the first car completed on February 26, 2013.

The Chinese government is supporting the development of FCVs and Figure 1 shows the universities, research centers and companies invovled. About 190 FCVs have been produced in China as of the end of 2011, with many models using the same stack developed by the coaltion shown in the figure. In addition, SAIC of China (who is GM's joint venture partner in China) will develop some FCVs using the GM stack. We are not aware of specific numerical targets for the number of FCVs in China for 2015, but presentations suggest that the total could be around 300 to 400 .

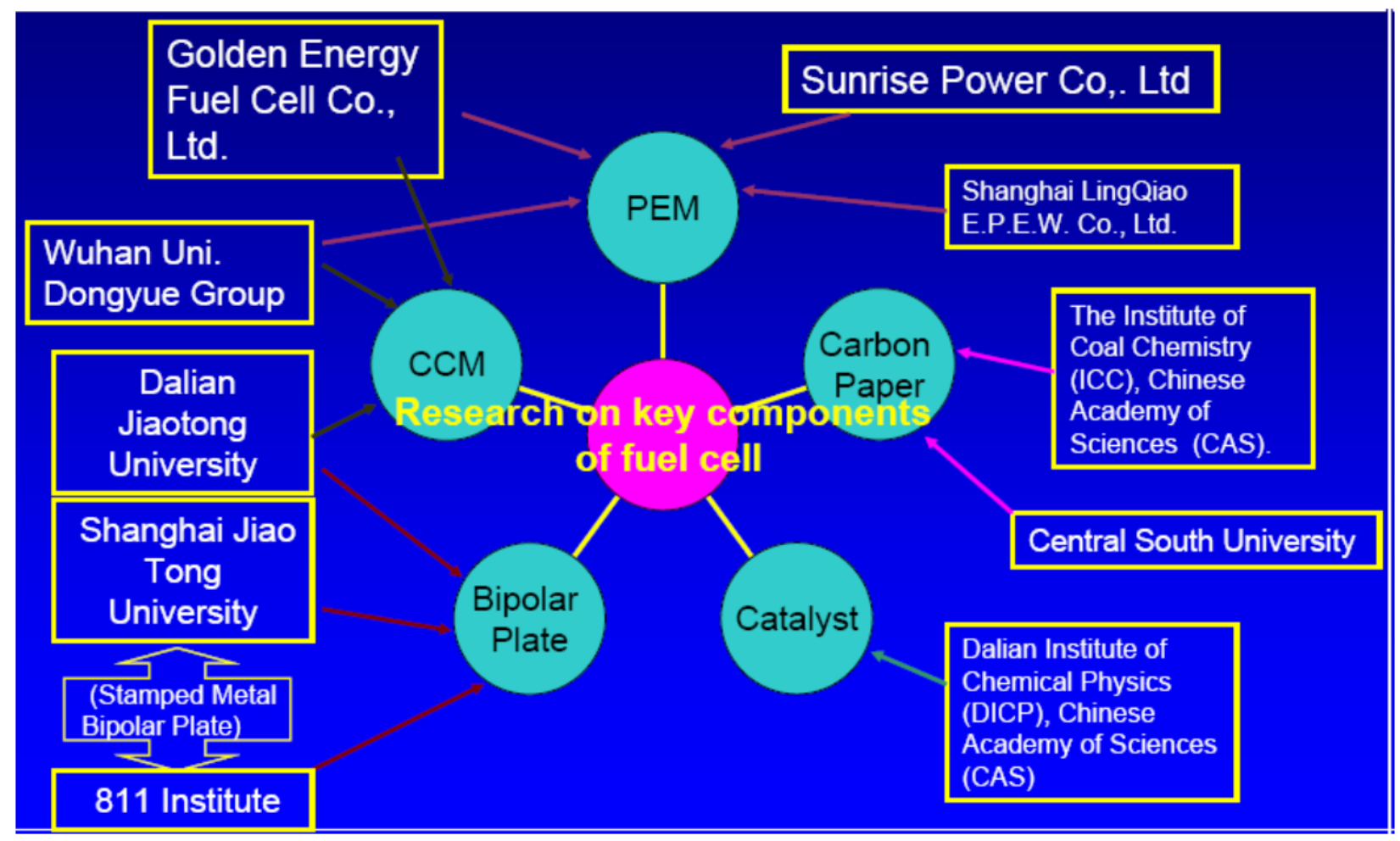

Figure 1. Chinese Organizations Involved in Fuel Cell Research.

Source: Dr. Tong Zhang, The Development of Fuel Cell vehicles in China, Presented at the Society of Fuel Cell Vehicle Manufacturers meeting, Shangai, China, September 21, 2010. 


\subsection{STACK PERFORMANCE}

Substantial development in stack performance and FCV performance has occurred in the past 4-5 years, and four of five OEMs seem to be relatively close to each other in terms of design approach, specific output and efficiency. Hyundai is unique in using a fuel cell that operates at low pressure (close to atmospheric) while other teams have adopted a strategy of boosting operating pressure to 1.8 to 2.2 bar (gage) to obtain high output from a smaller stack with some loss of efficiency at high output associated with the energy loss for gas compression. ${ }^{1}$

Honda has been the leader in developing high output fuel cell stacks, and Figure 2 shows the development of output over time, both in terms of specific energy per unit weight and per unit volume. In 2006, Honda's fuel cell stack had an output of $1.5 \mathrm{kw} / \mathrm{kg}$ and $1.9 \mathrm{kw} / \mathrm{L}$ and this stack was incorporated into the 2009 Honda Clarity. The stack used in the 2009 Clarity operated at 100 $\mathrm{kPa}$ gage pressure ( 1 bar). More modern stacks of 2010-2011 vintage developed by all manufacturers have higher output through increased boost pressure ( 2 bar) and higher current density and the level is estimated to be about $30 \%$ better than that of the previous generation, at $1.9 \mathrm{~kW} / \mathrm{L}$ and $2.5 \mathrm{~kW} / \mathrm{L}$, as shown in Figure 3.

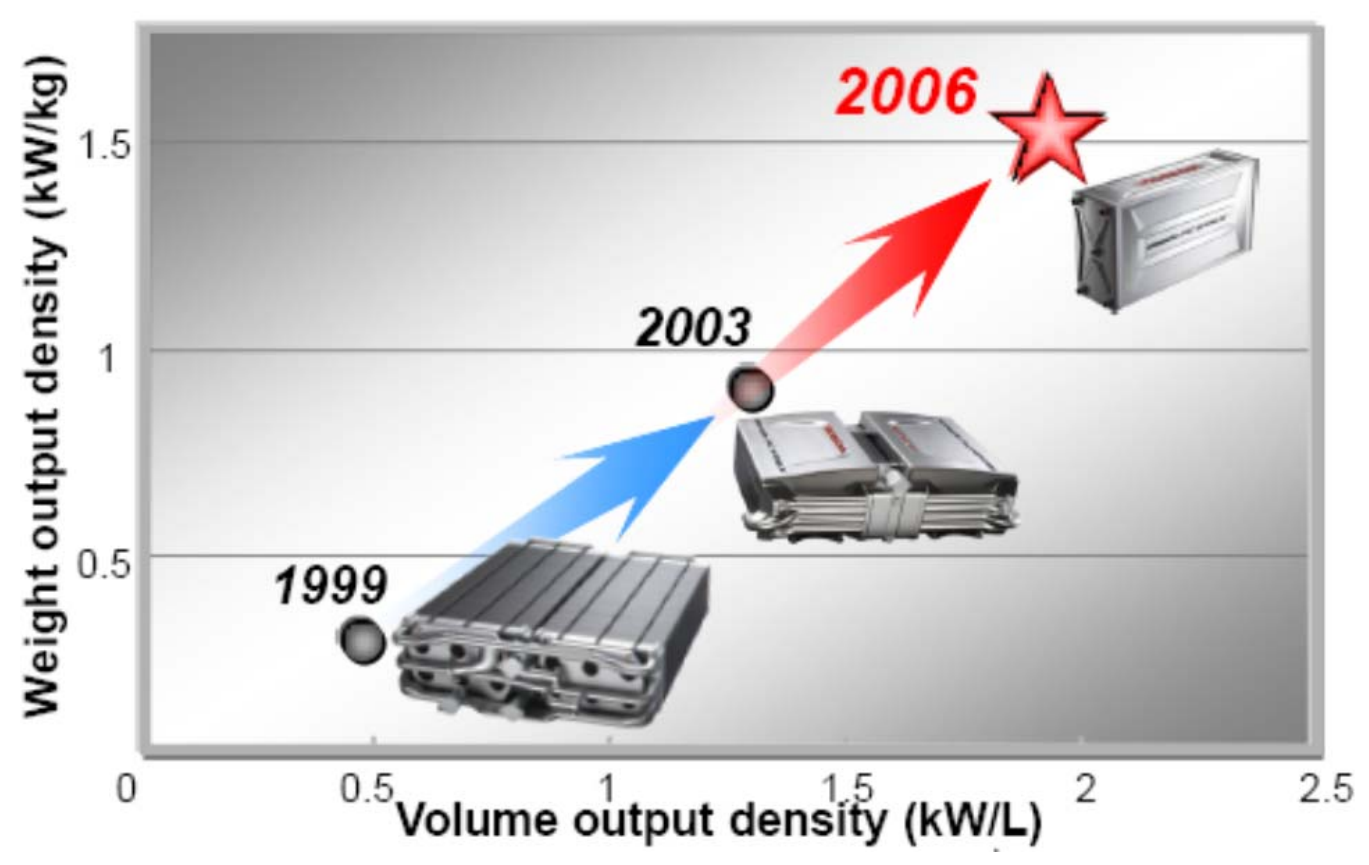

Figure 2. Evolution of Honda's Fuel Cell Stack Performance.

Source: Honda, Fuel Cell Electric Vehicle Development at Honda, Presentation at Site Visit, August 2012.

${ }^{1}$ James et al. (2013) concluded that a pressure of $3 \mathrm{~atm}$ (atmospheres) was optimal from the perspective of minimizing cost, up from 2.5 atm in the 2012 study by James and Spisak (2012). Future stacks may therefore have higher pressures. 


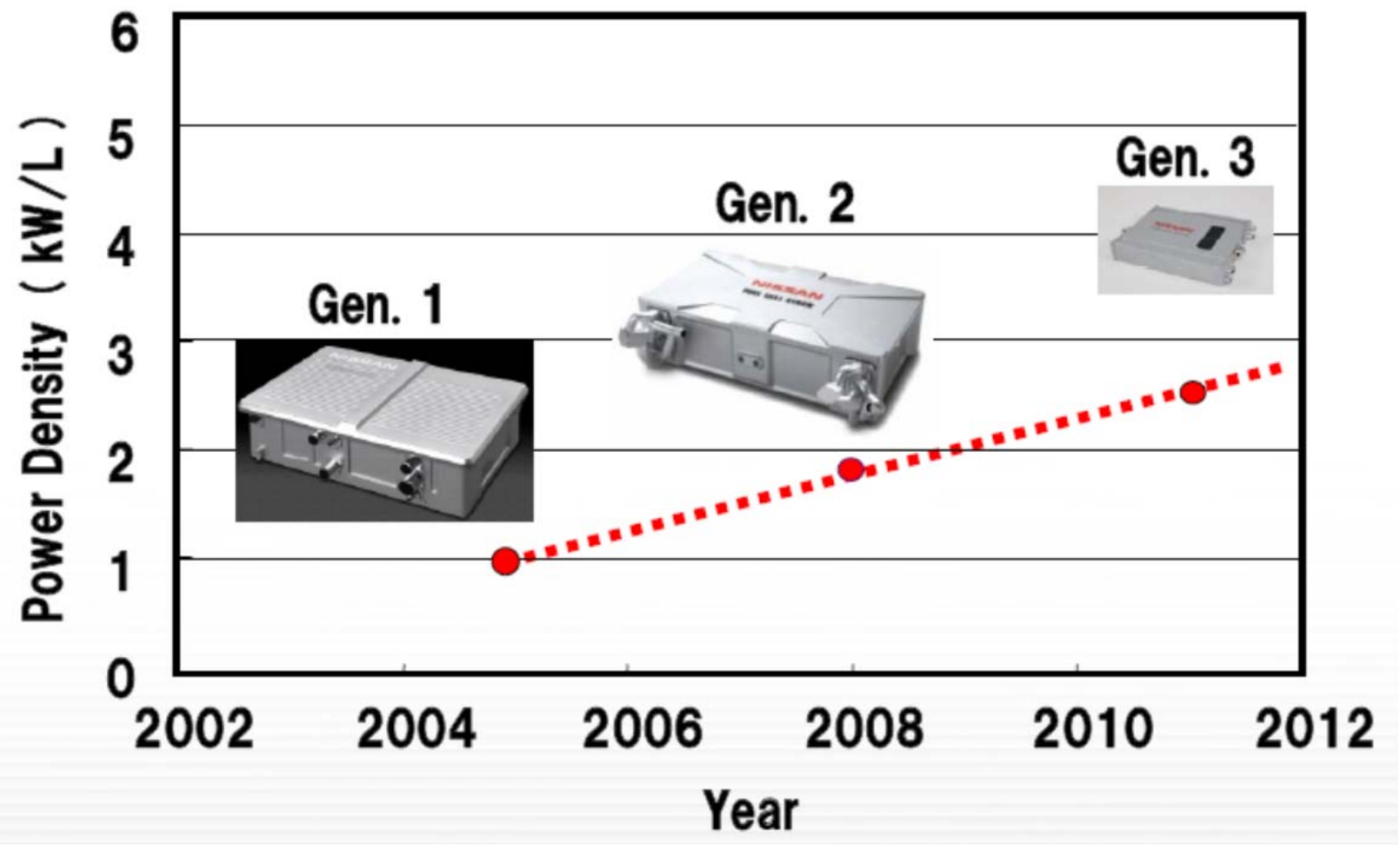

Figure 3. Stack Characteristics from Nissan.

Source: FCV Research and Development at Nissan, Presentation at Site Visit, August 2012.

The large increase in performance over the 2000 to 2010 period was primarily as a result of three major developments (Figure 4). First, the bi-polar plate was changed by Honda in 2006 from a machined graphite plate to a stamped coated metal plate with significant weight and size reduction. Second, the use of thinner organic membranes and improved cell structure design with higher boost pressure has improved the output per cell, with attendant reductions in weight per unit output, as shown in the schematic from Honda below. At present, all manufacturers are using metal bi-polar plates although some continue to use improved Nafion membranes rather than organic membranes. Third, increases in operating pressure from around 0.2 bar to 2 bar through improved sealing technology has increased peak output capability. 


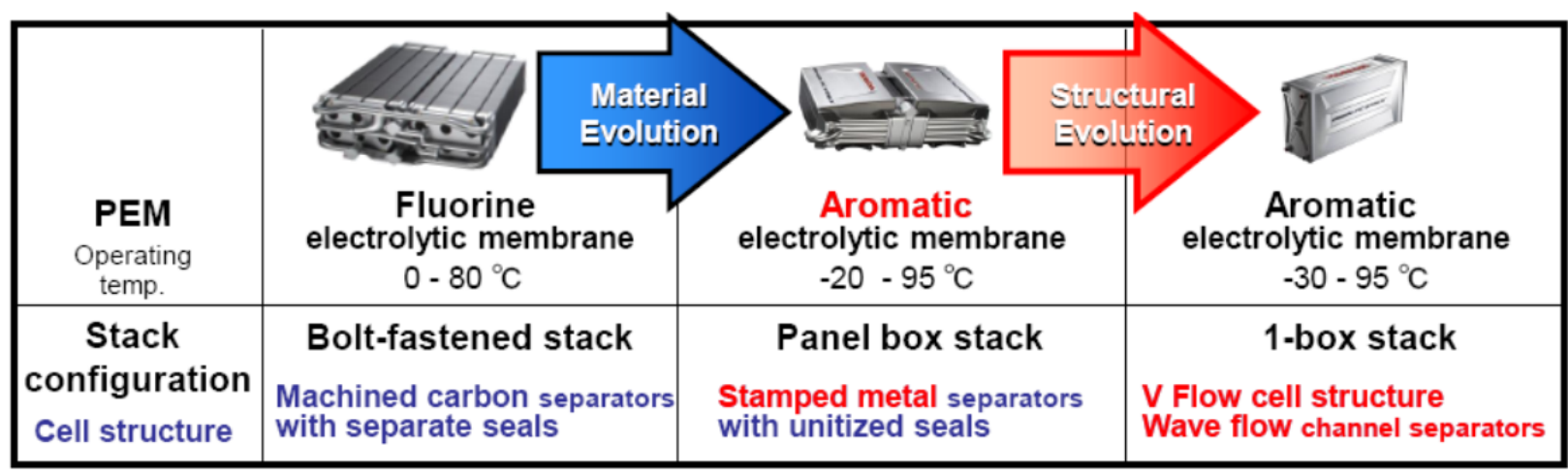

Figure 4. Improvements in Stack Technology Responsible for Higher Power Density.

Source: Honda, Fuel Cell Electric Vehicle Development at Honda, Presentation at Site Visit, August 2012.

Future improvements will come from the use of improved membranes, improvements in cell design and increased operating temperature but are unlikely to produce such large gains. Experts interviewed suggested improvements in the 15 percent range for the stacks in the first production vehicles for 2016, which would imply specific power levels of 2.15 to $2.2 \mathrm{kw} / \mathrm{kg}$ and 2.8 to 2.9 $\mathrm{kw} / \mathrm{L}$. Future generations of stacks with a new generation appearing every 5 to 6 years may see even smaller improvements per generation.

The platinum content of stacks has also been greatly reduced over the last decade. While platinum loadings for a complete fuel stack with output of 80 to $90 \mathrm{~kW}$ were over 200 gm prior to 2001, loadings declined to below 100 gm by 2005 and are currently at around 30 to 35 gm. Figure 5 shows the evolution of the GM stack from 2005 to 2010 and all manufacturers interviewed stated that 0.3 to $0.35 \mathrm{~g} / \mathrm{kW}$ output was the norm for current design stacks. However, we note that the GM stack appears to operate at low pressure as the stack size for the 2010 version is stated to be $64 \mathrm{~L}$, implying an output of $1.4 \mathrm{~kW} / \mathrm{L}$, about half the level currently reported by leading OEMs. The uniformity of catalyst loadings across OEMs is surprising as the higher output levels from operation at higher pressures should require higher catalyst loadings. The platinum content target for 2016 is in the 0.15 to $0.2 \mathrm{~g} / \mathrm{kW}$ range and it is acknowledged that these levels can be attained currently only with an unacceptable loss of durability, efficiency and peak output. Methods to reduce platinum content without reduction of peak power or fuel cell life are being developed based on techniques used in catalysts for engine emission control; these are described further in the section of fuel cell life. 


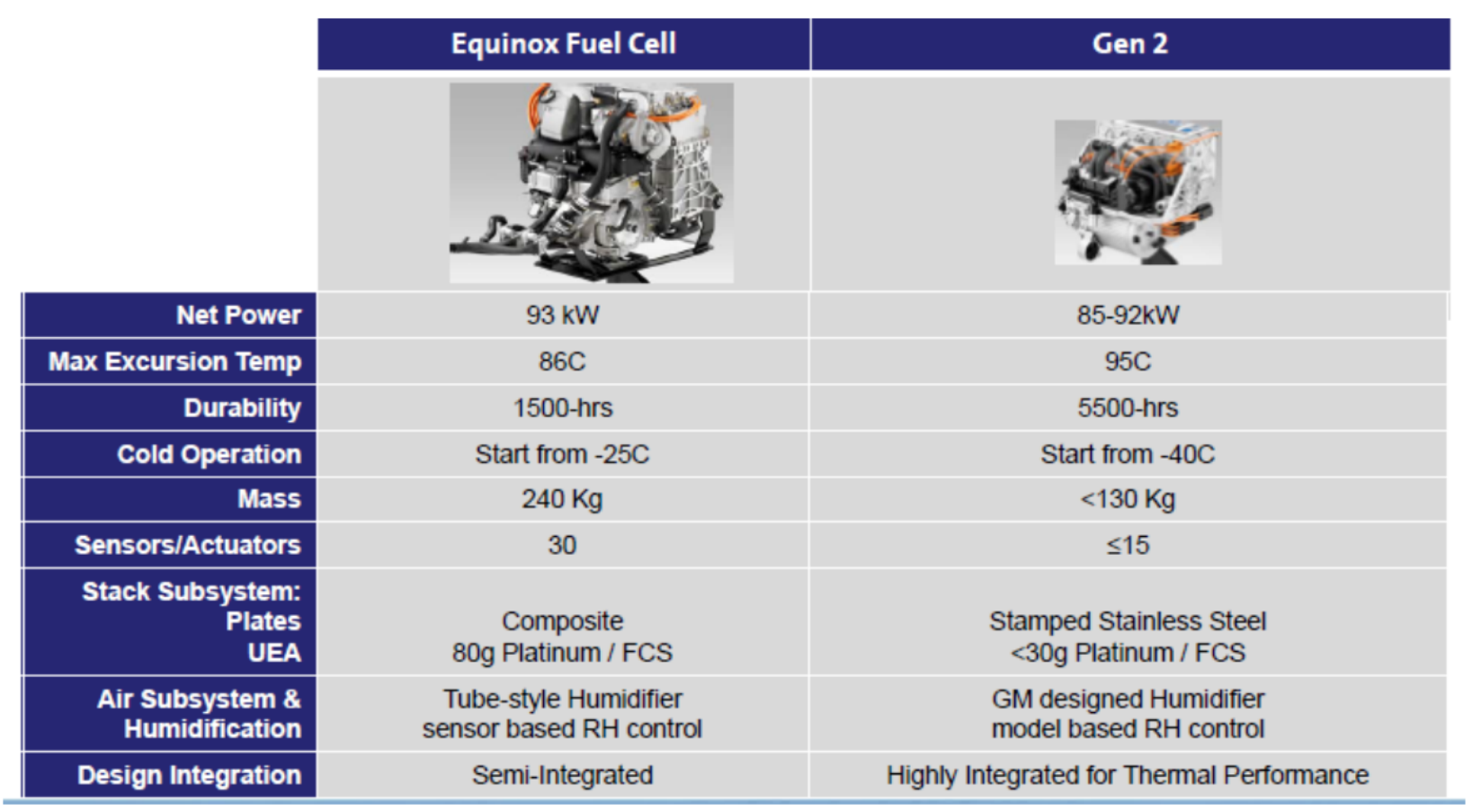

Figure 5. Development of GM's Fuel Cell Performance from 2005 to 2010.

Source: G.P. Hansen, GM Electrification Strategy with Focus on Hydrogen and Fuel Cell Vehicles,” International Partnership for Hydrogen and Fuel Cells in the Economy, Shanghai September 2010.

Fuel cell cold start performance is no longer considered to be a problem. Reliable starts have been demonstrated to $-15^{\circ} \mathrm{C}$ in fuel cells installed in vehicles and to $-25^{\circ} \mathrm{C}$ in the laboratory. Experts believe that cold starts can be accomplished with only a few seconds of waiting time and cold starts below $-25^{\circ} \mathrm{C}$ is an issue only for very limited geographical areas. However, some experts cautioned that repeated cold starts at very low temperatures can have a large negative effect on durability of the stack. Other experts believe that these effects can be minimized with an appropriate cold ambient shutdown procedure that pre-conditions the stack for cold start.

Stack efficiency is a function of load and usually is highest at light load (15 to 20\% of maximum output) and declines at high load. Peak efficiencies of about $68 \%$ to $70 \%$ are the norm at low pressure but with higher boost pressures peak efficiencies are one to two percent lower at light loads. At full load, modern stacks have an efficiency of 54\% to 55\% which is, again, lower than $57 \%$ to $58 \%$ for stacks operating at low pressure. Cycle average efficiencies on the EU test cycle or the Japanese cycle were stated to be in the $60 \%$ to $63 \%$ range, and this level of cycle efficiency was thought to be possible for the federal test procedure (FTP) cycle as well. 


\subsection{STACK DURABILITY}

The National Renewable Energy Laboratory (NREL) (Wipke et al., 2012) has been studying the durability of stacks in actual on-road use since 2004, and has documented the significant progress in durability as defined by hours of use for voltage degradation of $10 \%$ or less. First generation FCVs with cells of 2002-2003 design vintage had an average stack life of 821 hours, while second generation stacks of 2005-2006 design vintage had an average life of 1,062 hours. Third generation stacks of 2008-2009 design vintage improved significantly with an average life of 1,748 hours. Maximum life observed was typically higher by a factor of two or more. Some manufacturers suggested that the $10 \%$ voltage drop point may not be critical and $15 \%$ to $20 \%$ reduction at the end of useful life may be acceptable

As noted in the NREL report, the duty cycle of the FCV has a strong effect on fuel cell degradation, and this was confirmed in our interviews with auto manufacturers. A study by Nissan identified load cycling, time spent idling and the number of start-up cycles to be the most important duty cycle variables. Ambient temperature effects may also be a significant factor at colder temperatures but this effect has not been well characterized. The Nissan analysis suggests that load cycling may be the largest factor affecting deterioration in U.S. style driving as shown in Figure 6. Since FCVs also include a battery, some of the load cycling issues can be compensated for by designing the power control system to rely more on the battery for higher frequency power transients than with an internal combustion engine based hybrid, and possibly, by increasing battery size.

The mechanism of fuel cell degradation has been extensively researched and the main causes are corrosion of the carbon anode/cathode and the dissolution of platinum. The high potential between anode and cathode at start-up and during idle appear to cause carbon corrosion while the load cycling appears to be responsible for platinum dissolution. The carbon corrosion issues have been minimized through proprietary anode and cathode coatings, and platinum related issues are being addressed through changing the nanostructure of platinum coatings of the membrane, and by using higher platinum loadings to maintain stack performance for 2500 hours or more. 


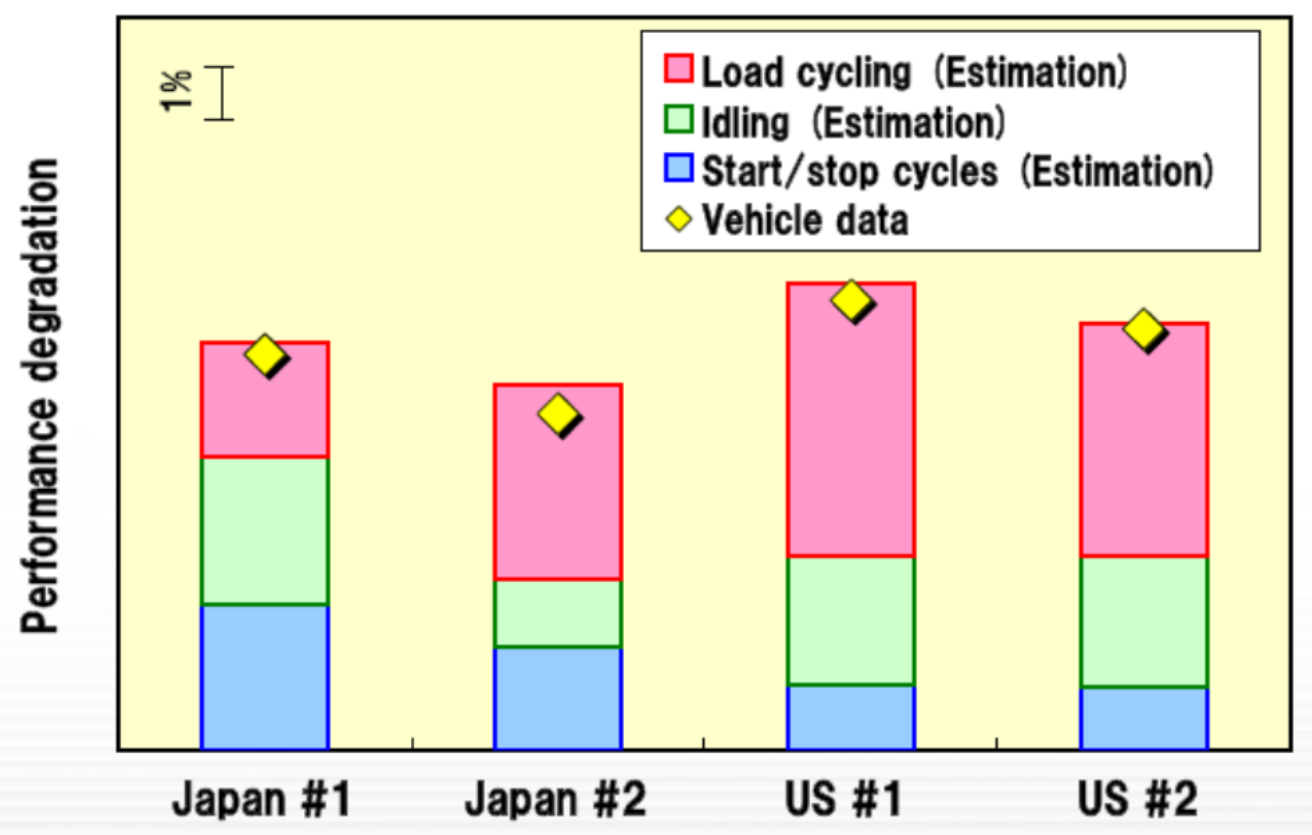

Figure 6. Duty Cycle Effects on Stack Performance Degradation.

Source: FCV Research and Development at Nissan, Presentation at Site Visit, August 2012.

Figure 7 shows GM's roadmap for the reduction of platinum for its $90 \mathrm{~kW}$ stacks and as noted, most manufacturers expect any products for 2015-2016 to incorporate about 30 gm platinum per stack. Many manufacturers view the platinum loading as a risk issue and state that the 0.3 to 0.35 gm per $\mathrm{kW}$ stack output level would ensure good durability for 15 years but 0.15 to 0.2 gm per $\mathrm{kW}$ output may be adequate with higher risk of stack output becoming unacceptable before 15 years. A few manufacturers were skeptical that a loading of 0.15 to $0.2 \mathrm{~g} / \mathrm{kW}$ was feasible without unacceptable trade-offs until 2020 or later. Only one manufacturer suggested that platinum cost was not a major issue at the current time as the cost differential between a 0.3 and $0.15 \mathrm{~g} / \mathrm{kW}$ was only on the order of $\$ 600$ to $\$ 700$, while total fuel cell system's current cost was higher by two orders of magnitude. 


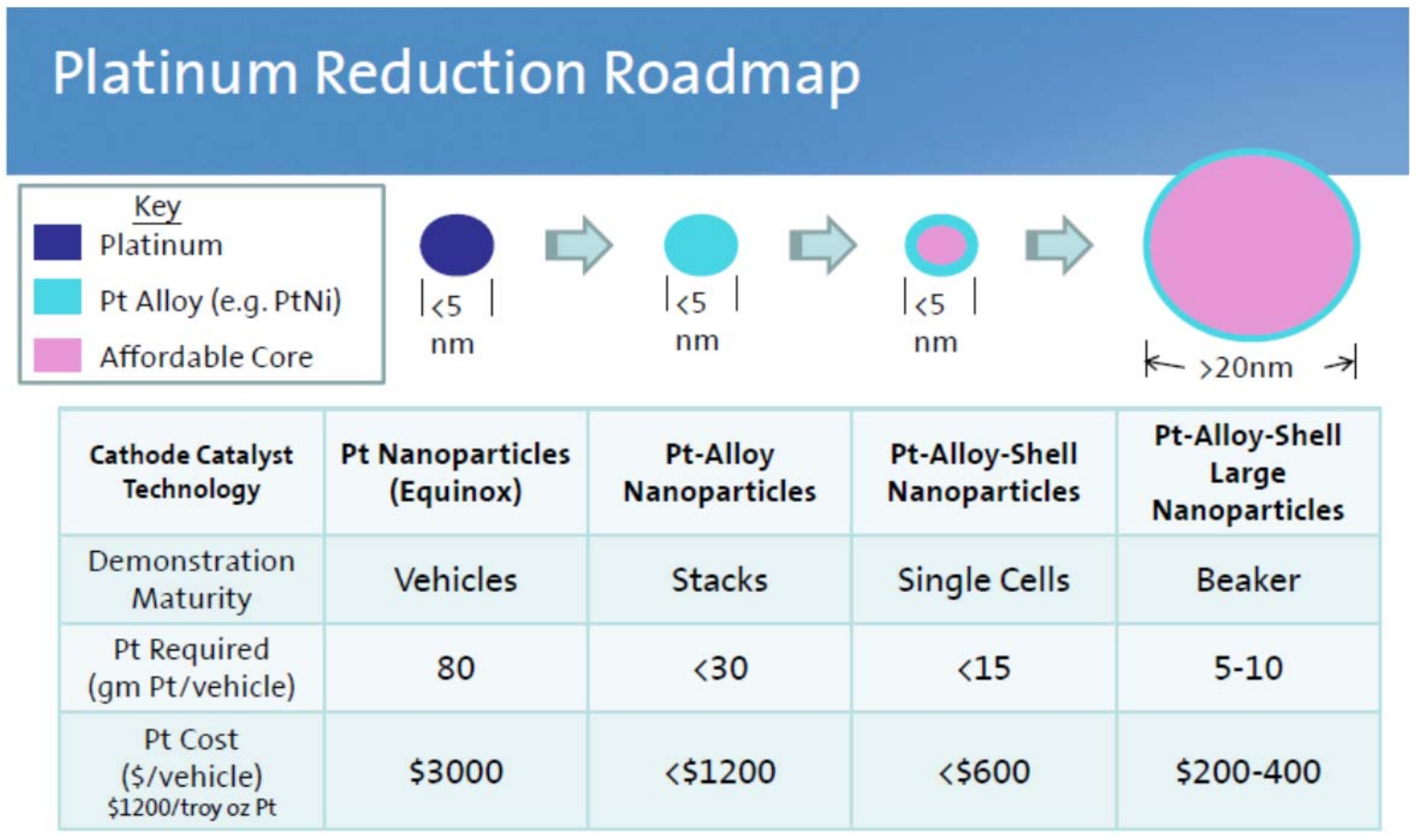

Figure 7. Platinum Loading Reduction Anticipated by GM.

Source: G.P. Hansen, “GM Electrification Strategy with Focus on Hydrogen and Fuel Cell Vehicles,” International Partnership for Hydrogen and Fuel Cells in the Economy, Shanghai September 2010.

In summary, it appears that manufacturers are confident about meeting a durability goal of a 15 year stack life with a platinum loading of 0.3 to $0.35 \mathrm{~g} / \mathrm{kW}$ in 2015 , but less confident of attaining a 0.15 to $0.2 \mathrm{~g} / \mathrm{kW}$ level with acceptable durability before 2020 or later.

\subsection{BALANCE OF PLANT AND HYDROGEN STORAGE TANKS}

While the stack is the most unique aspect of FCVs, the balance of plant and hydrogen storage are areas where although significant advances have been made yet further improvements are needed.

The balance-of-plant (BoP) includes all of the heat exchangers, flow control and air compression and humidification systems to enable stack operation. While first and second generation systems have used specialized, purpose-designed sub-systems, the trend is to move to commercially available components to reduce costs, and to simplify the BoP system. For example, the next generation stack design from Toyota will be targeted to eliminate the need for a separate humidifier for the air intake. The electrically driven air compressor is still a high cost item as commercially available compressors do not have the appropriate mass flow rates and pressure ratios required for fuel cells to maintain their water balance (the amount of water required to humidify the intake air relative to the amount of water being produced by oxidation of 
hydrogen). Research in this area suggests that a twin-screw compressor may offer a low cost solution although its net efficiency is quite low at about $40 \%$ to $45 \%$.

The hydrogen storage tanks are also a very high cost and bulky component. The auto industry has agreed to a 700 bar storage pressure standard and currently, the tanks, pressure relief valve and pressure regulators for 700 bar hydrogen storage are very high cost items that are available from only three or four suppliers globally. Toyota is developing its own storage tank technology. Their own tanks will target reducing the usage of high cost carbon fiber which is affected by the length to diameter ratio of the tank. In addition, current (2008) tanks use expensive aerospace grade fiber but Toyota is investigating the use of lower cost, general grade carbon fiber for storage tanks. They are targeting that the gravimetric density of hydrogen storage will be higher than 5\%. In addition, Toyota's experts also believe that current pressure regulators and relief valves are very overdesigned and use expensive high strength materials, and simpler designs with lower cost materials may be heavier but will offer significant cost reductions.

\subsection{TECHNOLOGY STATUS SUMMARY}

Substantial improvements in FCV technology have occurred over the last five years and the next generation of stacks due in 2015-2016 are certain to show additional improvements. Relative to stacks of 2005-2006 design vintage, these stacks will have

- $\quad$ a specific power level of $2.2 \mathrm{~kW} / \mathrm{kg}$ and $2.9 \mathrm{~kW} / \mathrm{L}$ for the stack which is a near doubling of specific power levels in 10 years, for stacks that operate at 2 to 2.5 bar pressure;

- a platinum loading of about 0.3 to $0.35 \mathrm{~g} / \mathrm{kW}$ of output, which is a factor of 3 reduction in loadings in 10 years, with improved stack life;

- a stack life at this level of platinum loading that should provide 12 to 15 years of vehicle durability with loss of power of $10 \%$ or less, which is a doubling of life in 10 years;

- $\quad$ an overall vehicle cycle efficiency percentage that is in the low 60s; and

- adequate on board hydrogen storage at 700 bar to provide for a vehicle range of up to 400 miles.

Given these developments, all manufacturers interviewed are confident that FCVs can meet the technical requirements for market introduction in 2015. The focus has now shifted to cost reduction and refueling infrastructure for future deployment and market development. 


\section{MANUFACTURING COSTS}

The cost estimates for FCVs and components presented in this section are based on information provided by German, Japanese and Korean manufacturers in discussions that occasionally included confidential information. For this reason, OEMs are not mentioned by name. The estimates are compared with other sources, including public statements and publications by OEMs and the recent EU study conducted by McKinsey \& Co. The estimates should be interpreted as the authors' best effort to discern the OEMs' perceptions of FCV costs today and over the next decade.

In all the cost estimates below, it is assumed that the base "glider" or vehicle without a powertrain is a conventional internal combustion engine (ICE) powered vehicle produced at high volumes, and that all of the cost differences are accounted for by replacing the ICE, its supporting systems and the gasoline fuel system with a fuel cell, electric drive system and hydrogen fuel system. In addition, the incremental costs (relative to the one in the conventional vehicle) of an electric heating, venting and air conditioning (HVAC) system and an electrically boosted regenerative braking system are often, but not always, added. This assumption may not be strictly true since the base glider may have to be structurally modified to include the hydrogen storage tanks and the vehicle front end may have to be modified for crashworthiness if the fuel cell and electric motor drive are larger than the equivalent ICE in volume and differ in rigidity. If the FCV is produced at high volumes, these structural modifications have only a small effect on total cost, but the effect on cost at low volume production may be significant.

Cost data is generally considered highly confidential by auto manufacturers and so it is useful to compare the information provided by OEMs to publicly available sources. Several manufacturers have publicly released some data on FCV costs. In addition, the German fuel cell organization NOW sponsored a study that collected confidential cost data from nine auto manufacturers in a very detailed study of FCV costs, but only some of the cost information is available publicly. Details of cost estimation procedures are only described very generally in the study, and it is unclear if all manufacturers had to use "consensus" estimates for the impact of scale economies and learning based cost reduction in the future, or if manufacturers could use their own estimates. In addition, the published cost data identifies only the year of the projection but is not explicit about the volume assumptions per model of FCV. The U.S. National Research Council (NRC) also recently released a study that included fairly detailed estimates of the current and future costs of FCVs, assuming high-volume and fully-learned production methods.

A further caveat is that the term "cost" is often not precisely defined by those providing information, in that many estimates include not only the direct costs of labor, materials and energy inputs but may also include engineering and development costs and the amortization of tooling and machinery. Administrative costs and sales and marketing overhead, as well as dealer 
costs are typically not included in “cost” but in sales price estimates but the burden rate assumptions may be different.

\subsection{THE EU GOVERNMENT/INDUSTRY POWERTRAIN STUDY}

The cooperative government/industry study conducted by McKinsey \& Co. (2011) for the National Organisation Wasserstoff (NOW) is the only publicly available comprehensive source of manufacturer provided data on FCV and component costs. It is useful to review the study's estimates of fuel cell stack costs and FCV costs as a point of comparison for estimates more recently provided to us by manufacturers. The study assumes a net markup of $21 \%$ from “cost.” The percent markup is applied to the cost of a conventional vehicle and the absolute amount is then added to other vehicles, rather than applying the $21 \%$ markup to the manufacturing cost of alternative vehicles. The U.S. Environmental Protection Agency (EPA), for example, applies a markup of $50 \%$ to $60 \%$ from variable cost where the cost is defined as the cost of a sub-assembly (such as a complete fuel cell stack) delivered from a supplier to an auto manufacturer's assembly plant. The supplier can be independent or a division of the manufacturer. Hence, it appears that the McKinsey study's cost estimates already include engineering and tooling costs and factory and management overhead.

McKinsey’s estimates of fuel cell stack costs by component for three specific years but both production volume and stack technology for three points in time are shown in Table 1 . The production volumes are based on statements about the cumulative number of FCVs, with one million FCVs in the EU by 2020, while the 2010 volume is based on typical assembly rates of FCVs planned in that time frame but not actually put into place. The study also found that cost estimates varied considerably across manufacturers; for 2015, the cost estimates varied by $273 \%$ from the lowest to highest estimate.

Table 1. McKinsey (2011) Study Cost Estimates (in Euros) for a 85 kW Stack (conversion to US\$ based 1 Euro $=1.25$ US\$)

\begin{tabular}{lccc}
\hline $\mathbf{8 5}$ kW Stack & $\mathbf{2 0 1 0}$ & $\mathbf{2 0 1 5}$ & $\mathbf{2 0 2 0}$ \\
\hline MEA & 14,275 & 2,970 & 1,045 \\
Catalyst & 6,295 & 3,195 & 1,420 \\
Structure & 22,230 & 3,210 & 1,050 \\
BoP & 38,565 & 9,515 & 3,960 \\
\hline Total (Euro) & 81,365 & 18,890 & 7,475 \\
\hline Total US\$ & $\mathbf{1 0 1 , 7 0 0}$ & $\mathbf{2 3 , 6 0 0}$ & $\mathbf{9 , 3 5 0}$ \\
\hline Volume (inferred) & $\sim 200 /$ YR & $\sim 20,000 / Y R$ & $\sim 200,000 /$ YR \\
\hline
\end{tabular}

Details on total power-train costs and the net vehicle cost and price are provided only for 2020 for European C/D segment cars (approximately equivalent to a midsize U.S. car). Based on all the data in the report, we have estimated 2015 component costs and inferred total vehicle costs 
using the learning and improvement rates specified in the report. These estimates are shown in Table 2.

Table 2. McKinsey (2011) 2020 Cost (Euros) and Estimated 2015 Costs for a Midsize FCV

\begin{tabular}{lcc}
\hline Cost in Euros & 2020 & 2015 \\
Fuel cell stack & (McKinsey, 2011) & (estimated) \\
Hydrogen storage & 7,475 & 18,890 \\
Battery & 2,550 & 5,100 (estimated) \\
Electric Motor/Inverter/ Drive & 870 & 1,000 (estimated) \\
Total Powertrain & 3,630 & 5,110 \\
Electric HVAC/ Regen. Brakes & 14,525 & 30,100 \\
(incremental) & 300 & 675 \\
Glider & & 11,385 (assumed \\
& 11,385 & constant) \\
\hline Total FCV & & 42,160 \\
\hline Total FCV price pre-tax & 26,210 & $\sim 50,000$ \\
\hline
\end{tabular}

The 50,000 Euro price before taxes in 2015 is equivalent to a $\$ 62,500$ price. This price level for 2015 at production levels of about 20,000/year is generally agreed to by the manufacturers interviewed, in spite of the very large cost differentials among submissions to the McKinsey study. That report projects a FCV pre-tax price of $€ 25,700$ in 2030 but no volume details are provided. Nonetheless, this suggests that the bulk of the FCV cost reduction occurs in the 2015 to 2020 time frame; the 2030 costs appear to be largely a result of an assumed 2\% per year annual cost reduction through learning. It should be noted that European vehicle retail prices are significantly higher than U.S. prices, but the pre-tax estimate of European vehicle prices appears to be similar to U.S. retail prices; for example, the pre-tax price of a 2020 gasoline hybrid vehicle in the C/D segment is estimated at Euro 21,400 or U.S. \$26,750 which is approximately the U.S. retail price for a Camry or Fusion hybrid vehicle in 2012.

\subsection{MANUFACTURERS' COST ESTIMATES}

The individual auto manufacturers have publicly disclosed some data on FCV costs or cost distribution among sub-assemblies. In addition, manufacturers provided some confidential information on costs that is not disclosed here but included in our analysis of costs. Toyota has publicly stated that although currently a price under10 million yen seems attainable, Toyota aims to further reduce costs to bring the vehicle to market at a more affordable price. ${ }^{2}$ Hyundai has

\footnotetext{
${ }^{2}$ http://www.toyota-global.com/news/13/index.html
} 
also publicly stated ${ }^{3}$ that it expects costs of FCV to be around \$50,000 in 2015, and related figures in their presentation imply a sales volume of 10,000 in 2015. Hyundai is the only major manufacturer operating its stack at low pressure, and its ix35 model FCV also uses an induction motor for lower costs. Daimler has publicly stated ${ }^{4}$ that in high volume production (which we estimate is $200 \mathrm{~K}$ per year) they anticipate that the FCEV will be cost competitive with a dieselhybrid in the 2025 time frame. The total power train and tank cost for a diesel hybrid, with advanced emission control is expected by $\mathrm{H}-\mathrm{D}$ Systems to be in the $\$ 8,000$ to $\$ 8,500$ range, implying the potential for substantial cost reduction.

One OEM indicated that for 2015, the key FCV drivetrain components of stack, balance-of-plant, hydrogen storage and electric motor drive system each accounted for about one-quarter of total drivetrain cost. This distribution does not closely match the costs shown in Table 2; the McKinsey (2011) estimates suggest that the stack and BoP account for 31\% and 32\% of drivetrain cost while hydrogen storage accounts for only $17 \%$ of cost and the electric motor drive and battery accounts for $20 \%$ of cost. This suggests an overestimation of stack and BoP costs since other data obtained from OEMs and discussed below confirm the hydrogen storage and electric drive system costs in Table 2. An OEM also confirmed hydrogen storage costs at about $\$ 1,000 / \mathrm{kg}$ if tanks were produced in volume, which is consistent with the $€ 5,100$ estimate for 5.5 $\mathrm{kg}$ of hydrogen storage (including pressure regulator and valves).

In another OEM's view, fuel cell stacks can be the same price as an ICE, not considering the cost of the catalyst material, since the stack materials with the exception of the catalyst can be inexpensive and manufacturing processes are not inherently more complex. In 2015, the OEM expects the following breakdown: $30 \%$ to 35\% stack, 15\% BoP, $20 \%$ motor/controller, 5\% battery, $20 \%$ to $25 \%$ for the hydrogen tanks and pressure regulator for the drivetrain which will be about $80 \%$ of the vehicle cost. If the vehicle cost is $\$ 50,000$ the costs are as follows for a $100 \mathrm{~kW}$ stack and motor with 5.3kg hydrogen storage:

Fuel Cell stack: $\$ 12,000$ to $\$ 14,000$

Balance of Plant: \$6,000

Motor and Inverter/Controller: $\$ 8,000$

Tanks and Pressure regulator: $\$ 8,000$ to 10,000 .

Battery: $\$ 2,000$

Glider: $\$ 10,000$

Note that these are costs at low volume production of about 10,000/year, and typical retail price markups would suggest a vehicle price with full recovery of capital and R\&D costs as well as

\footnotetext{
${ }^{3}$ B.K.Ahn, Development of Fuel Cell Vehicle at Hyundai Motors, International Partnership for Hydrogen and Fuel Cells in the Economy, available at their website, www.ihpe.net

${ }^{4}$ A. Truckenbrodt, Fuel Cell Vehicles are Ready for Prime Time, World Hydrogen Energy Conference, Toronto, 2012 available at www.whec2012.com
} 
normal profit margins, of about $\$ 80,000$. This OEM’s cost breakdown suggests a much higher cost for the electric motor/inverter/controller and for the hydrogen tanks.

A third OEM estimates the cost breakdown for a 2015-2016 FCV as follows:

Fuel Cell Stack Cost Breakdown

- $\quad$ MEA: $42 \%$

- $\quad$ Rest of Stack: 13\%

- Bance of Plant: $40 \%$

- Hardware: 5\%

The stack cost for a production rate of $~ 30,000 /$ year is similar to that of the McKinsey (2011) study and is estimated at approximately $€ 18,000$. The OEM also estimated that the fuel cell system accounted for $43 \%$ of total power-train cost including hydrogen storage cost, suggesting a total powertrain and hydrogen storage cost of $€ 42,000$. Adding the glider (plus electric AC and regenerative brakes) costing about $€ 12,000$ results in a total FCV cost of $€ 54,000$. However, the cost breakdown suggested a relatively high cost for the motor cost and power electronics so that the fuel cell system cost may be even lower than the $€ 18,000$ estimate of the McKinsey study.

While there was a reasonable degree of consensus regarding 2015-2016 vehicle costs at production volumes in the 10,000 to 30,000 range per year, several manufacturers interviewed were skeptical about the estimates of very substantial cost reductions by 2020 and 2025. The near term costs are based on a well understood technical path to meet those goals while the 2020 costs do not have a recognized technical path. To attain the goal of building a fuel cell system for under \$5,000 in high volume, these manufacturers believed that a breakthrough was needed to allow the replacement of specialized materials for the anode, cathode and membrane by “commodity” materials. Vehicle cost reduction would require substantial reductions to the cost of hydrogen storage as well through a dramatic lowering of high strength carbon fiber costs. These manufacturers suggested that while these reductions were possible, it would be very unlikely to occur by 2025.

\subsection{THE COSTS OF FUEL CELL VEHICLES}

Based on the data presented in sections 3.1 and 3.2, as well as inputs from meetings with manufacturers, the central tendency estimates presented in this section were derived. Estimates of current production costs of $\$ 100,000$ to $\$ 120,000$ for a fuel cell system manufactured at $\sim 500$ to 1,000 units per year may not be meaningful. At these low volumes, estimates depend more on what costs are allocated to fuel cell assembly, and what suppliers quote for products that they produce or sell in very low volumes chiefly to maintain relationships with their OEM customers. 
There appears to be general agreement on the cost of an automotive fuel cell system in 2015-2016 at volumes of approximately 20,000/year. A reasonable estimate of the cost for a 85 $\mathrm{kW}$ stack, including the balance of plant is in the range of $\$ 24,000 \pm 1500$. Having said this, the breakdown of costs between BoP and stack cost varies, with some OEMs indicating nearly equal costs, but others estimating only about one-third of the cost for the BoP and two-thirds for the stack. Differences in the design of the OEMs' stacks can explain only part of the difference. One OEM estimates considerably lower fuel cell system costs of about $\$ 18,000$ to $\$ 20,000,20 \%$ to $25 \%$ less than the central tendency estimate.

Hydrogen storage costs have been extensively investigated by all manufacturers and several manufacturers mentioned that current costs do not provide a guide to what can be expected in the future. The current global supplier base for high pressure hydrogen storage tanks is limited and there has not been much investment by suppliers into mass produced tanks for automotive use. The cost of hydrogen storage is determined not only by the mass of hydrogen to be stored but also by the number of tanks. In high volume production of $100 \mathrm{~K}$ to $200 \mathrm{~K}$ units per year, publicly available data from BMW shown in Figure 8 below for 700 bar tanks suggests a cost of about $€ 3,500$ for storing $5 \mathrm{~kg}$ of hydrogen with a two tank system. It was not clear if the cost of the pressure regulator and tank valves were included, but these can add another $€ 500$ to $€ 700$ to total cost. The McKinsey (2011) report suggests a cost of $€ 5100$ in 2015-2016 but specific assumptions of tank production levels were not documented. At least one OEM believed that costs of about $\$ 6,000(€ 4,800)$ were reasonable for $5 \mathrm{~kg}$ storage at a 20,000 units/year production volume.

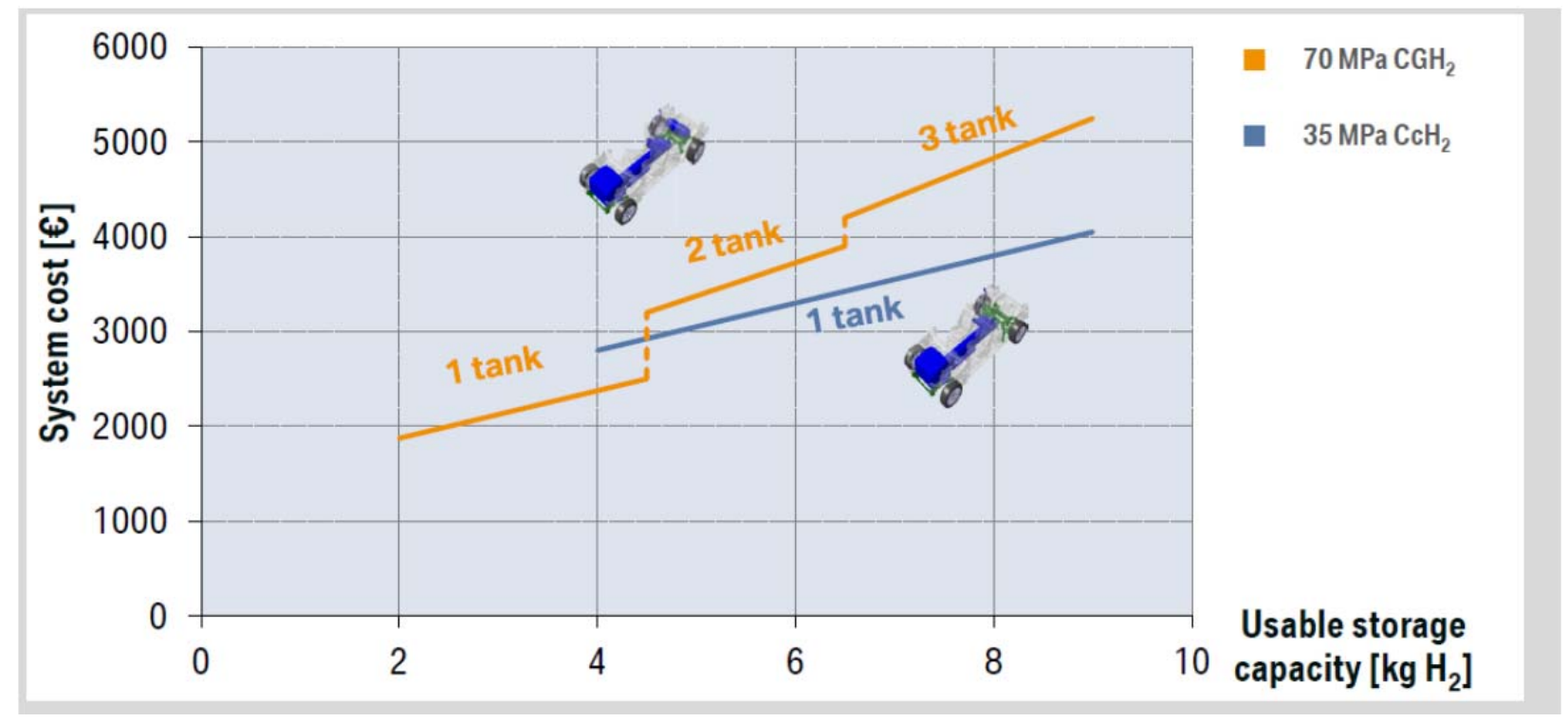

Figure. BMW Estimates of On-Board Hydrogen Storage Cost.

Source: Dr. K. Kunze, Performance of Cryo-compressed Hydrogen Storage, Presented at the World Hydrogen Energy Conference, Toronto, 2012. 
A more detailed study ${ }^{5}$ by Argonne National Laboratory (ANL) of tank costs at high production volumes of 500,000 units per year showed long-run costs of a 700 bar tank with $5.6 \mathrm{~kg}$ hydrogen storage capability at about $\$ 3,350$, as shown in Table 3. The cost of the carbon fiber was assumed to be $\$ 28.60 / \mathrm{kg}$ and is the biggest cost contributor to the overall tank cost. However, the ANL analysis assumed a high level of automation in manufacturing and assembly, and the report acknowledged that the net processing cost was very low compared to current (low volume) manufacturing methods.

Table 3. ANL (2010) Estimates of Hydrogen Storage Tank Cost at High Production Volumes $\left(5.6 \mathrm{~kg} \mathrm{H}_{2}\right)$

\begin{tabular}{|l|c|c|c|c|c|c|}
\hline \multirow{2}{*}{$\begin{array}{c}\text { On-board System Cost } \\
\text { Breakout - Compressed Gas }\end{array}$} & \multicolumn{2}{|c|}{ Type IV $\mathbf{3 5 0}$-bar Base Case } & \multicolumn{3}{c|}{ Type IV 700-bar Base Case } \\
\cline { 2 - 7 } & $\begin{array}{c}\text { Material, } \\
\mathbf{\$}\end{array}$ & $\begin{array}{c}\text { Processing, } \\
\mathbf{\$}\end{array}$ & $\begin{array}{c}\text { Processing } \\
\text { Fraction }\end{array}$ & $\begin{array}{c}\text { Material, } \\
\mathbf{\$}\end{array}$ & $\begin{array}{c}\text { Processing, } \\
\mathbf{\$}\end{array}$ & $\begin{array}{c}\text { Processing } \\
\text { Fraction }\end{array}$ \\
\hline Hydrogen & $\$ 18$ & (purchased) & - & $\$ 18$ & (purchased) & - \\
\hline Compressed Vessel & $\$ 2,193$ & $\$ 102$ & $4 \%$ & $\$ 2,681$ & $\$ 119$ & $4 \%$ \\
Liner \& Fittings & $\$ 20$ & $\$ 11$ & $34 \%$ & $\$ 14$ & $\$ 10$ & $43 \%$ \\
Carbon Fiber Layer & $\$ 2,111$ & $\$ 83$ & $4 \%$ & $\$ 2,619$ & $\$ 102$ & $4 \%$ \\
Glass Fiber Layer & $\$ 30$ & $\$ 7$ & $18 \%$ & $\$ 23$ & $\$ 6$ & $21 \%$ \\
Foam & $\$ 32$ & $\$ 2$ & $5 \%$ & $\$ 25$ & $\$ 1$ & $5 \%$ \\
\hline Regulator & $\$ 160$ & (purchased) & - & $\$ 200$ & (purchased) & - \\
\hline Valves & $\$ 226$ & (purchased) & - & $\$ 282$ & (purchased) & - \\
\hline Other BOP & $\$ 130$ & (purchased) & - & $\$ 155$ & (purchased) & - \\
\hline Final Assembly \& Inspection & - & $\$ 36$ & - & - & $\$ 36$ & - \\
\hline Total Factory Cost & $\$ \mathbf{2 , 7 2 7}$ & $\mathbf{\$ 1 3 8}$ & $\mathbf{5} \%$ & $\$ 3,334$ & $\$ 156$ & $\mathbf{4} \%$ \\
\hline
\end{tabular}

Manufacturers believed that the $\$ 3,350$ cost figure was optimistic but not unreasonably low if such high volumes could be attained. Some manufacturers are also exploring lower cost carbon fiber (non aerospace grade) to reduce costs. The projected costs of the regulator, valves and other hardware are also almost a factor of 10 lower than current costs but again, manufacturers believe that a substantial degree of simplification and cost reduction is possible through redesign. In general, very large cost reductions with increased production volume are not likely for tanks since the manufacturing process technology is quite similar between $20 \mathrm{~K}$ and $200 \mathrm{~K}$ annual output for tanks. Carbon fiber prices are more critical in determining the future cost of tanks and if current efforts to cut the cost of carbon fiber for automotive tank applications are successful, the $\$ 3,350$ estimate could be realized.

Finally, the present cost of the electric motor/inverter/controller is reasonably well known as motors in the $100 \mathrm{~kW}$ output range are in production of the Nissan Leaf and the Chevy Volt. One issue that has not been consistently addressed is the rating method. Most manufacturers specify

\footnotetext{
${ }^{5}$ T. Hua, et al., Technical Assessment of Compressed Hydrogen Storage Tank Systems for Automotive Applications, ANL Report No. 10/24, September 2010.
} 
the motor peak rating but this output can be sustained only for a short time without overheating. The peak ratings can be based on different times ranging from 10 seconds to 1 minute. Typically, the continuous rating is about half the level of a 30 second peak rating. Previous work ${ }^{6}$ by H-D Systems in the context of hybrid and battery electric vehicles has shown high RPM permanent magnet motor/inverter/controller costs to be $300+30 * \mathrm{~kW}$ (peak). For the $110 \mathrm{~kW}$ (30 second peak) rated motor, we expect the total cost to be $\$ 3,600$, which lies within the cost range of $€ 2,600$ to $€ 3,000$ Euro provided some manufacturers. The cost reductions with higher sales volumes are expected to be smaller as these costs already assume motor production of battery EVs. Induction motors (used by Hyundai's FCV) are expected to be $10 \%$ to $15 \%$ cheaper than the permanent magnet motor although there will be no saving in inverter and controller cost, so the net saving is on the order of $4 \%$ to $7 \%$.

In order to facilitate comparisons, costs for a D segment or midsize car (e.g., Ford Fusion, Toyota Camry) were estimated. In the United States, these vehicles have a current (2012) retail price of $\$ 22,000$ to $\$ 23,000$ for the base 4 cylinder model with a 6-speed automatic transmission. We use a 1.6 multiplier for the retail price to cost ratio, so that the factory gate cost with no overheads and no profit margin is estimated at about $\$ 14,000$, implying a retail price equivalent of $\$ 22,400$. Available data provides the following approximate break out of drive-train cost for a conventional car.

$\begin{array}{ll}\text { 4-cylinder PFI engine: } & \$ 1,400 \\ \text { 6-speed automatic: } & \$ 850 \\ \text { Exhaust system/catalysts } & \$ 330 \\ \text { Fuel Tank/pump/lines: } & \$ 200 \\ \text { Engine Control unit } & \$ 180 \\ \text { Evaporative Controls } & \$ 70\end{array}$

Total costs are about $\$ 3,000$ so that the equivalent "glider" cost is estimated at $\$ 11,000$. (Because of significant cost variations among manufacturers, the values above should be understood as approximate industry averages with a $\pm 10 \%$ variation).

The derivation of costs for the FCV starts from the consensus cost estimates for the 2015-2016 FCV produced at volumes of 20,000 per year. The estimates assume 200,000 per year production in 2015-2016 using the following rules.

- $\quad$ For the fuel cell stack and balance-of-plant, we have used a scale elasticity of 0.2 , but recognize that the actual value is not well understood as fuel cells have

\footnotetext{
${ }^{6}$ H-D Systems (under subcontract to CE Delft), Assessment of Electric Vehicle and Battery Technology, Report to the EU Directorate of Climate Change, December 2010.
} 
never been produced in high volume. The -0.2 value is a typical mid-range value for many automotive components.

- Hydrogen storage tanks and pressure regulators are expected to significantly lower economies of scale and suppliers suggest that a scale elasticity of -0.1 may be appropriate.

- $\quad$ Electric motors/inverters/controllers are already assumed to be manufactured at high volumes ( 200K/yr) for hybrid and battery electric vehicles and the scale would increase by a factor of 2 if FCEVs were also manufactured at 200K/year. Scale elasticity is assumed to be -0.2 .

Based on these assumptions, the estimated cost of the FCV in 2015-2016 at two different production volumes are shown in Table 4.

Table 4. Central Tendency Estimates of FCV Cost at 20K/yr Production Volume Extrapolated to 200K/yr Volume

\begin{tabular}{lcc}
\hline Cost in \$ & $2016(20 \mathrm{~K} / \mathrm{yr})$ & $2016(200 \mathrm{~K} / \mathrm{yr})$ \\
\hline Fuel cell stack $(85 \mathrm{~kW})$ & 24,000 & 15,150 \\
Hydrogen storage $(5 \mathrm{~kg})$ & 6,700 & 5,300 \\
Battery $(35 \mathrm{~kW}, 2 \mathrm{kWh})$ & 1,500 & 1,300 \\
Electric Motor/Inverter/ Drive & 3,600 & 3,150 \\
$(110 \mathrm{~kW}$ peak, 60kW continuous) & & \\
GearboX & 400 & 350 \\
Total Power-train & $\mathbf{3 6 , 2 0 0}$ & $\mathbf{2 5 , 2 5 0}$ \\
Electric HVAC/Regen. Brakes & 800 & 750 \\
(incremental) & & \\
Glider & 11,000 & $\mathbf{1 1 , 0 0 0}$ \\
Total FCV cost & $\mathbf{4 8 , 0 0 0}$ & $\mathbf{3 7 , 0 0 0}$ \\
\hline
\end{tabular}

The cost shown in Table 4 would result in a retail price equivalent (RPE) of about $\$ 77,000$ at low volume and \$59,000 at high volume, if manufacturers charged “normal” administrative, management and cost recovery overheads and a profit margin of $7 \%$ to $8 \%$. Initially manufacturers would likely forego the overheads and markup the vehicle only to cover dealer and marketing costs and warranty costs, which typically are about $16 \%$ to $20 \%$ of total costs. This would place the RPE at low volume in the $\$ 55,000$ to $\$ 58,000$ range, which is reasonably consistent with public statements by manufacturers. At 200K/year production, manufacturers cannot forego all overheads, so that retail prices will likely be held constant in the $\$ 55 \mathrm{~K}$ to $\$ 58 \mathrm{~K}$ range, even with increasing volume.

Costs in the vicinity of 2020 are expected to change significantly due chiefly to much higher volume production. As noted in Section 2, some manufacturers expect that there will be technology breakthroughs to reduce fuel cell stack and BoP costs by a factor of two, from 2016 costs, but others are skeptical. In the absence of a breakthrough, it is reasonable to expect some decline in stack and motor costs form learning: a $2 \%$ per year reduction is assumed. In the 
"breakthrough" case, we have used the manufacturer expectation that stack costs can be reduced by the use of commodity materials for the MEA and available automotive components for the $\mathrm{BoP}$. We have also modeled the use of advanced induction motors that, with inverter and controller cost changes accounted for, are expected to cost 15\% less than a PM motor albeit with some loss in efficiency (one OEM is already following this strategy). In all cases battery costs are expected to decline by $30 \%$ with packaging and chemistry improvements. Hydrogen storage costs could decline to the values expected by Argonne if lower cost automotive grade fiber becomes widely available.

The net vehicle costs for the 2020 time frame under the two scenarios are shown in Table 5. The equivalent vehicle RPE declines only to about $\$ 53,000$ in the non-breakthrough case but declines to $\$ 42,000$ in the breakthrough case. In both cases, however, we assume no change to the weight of the glider. However, it has been pointed out that with a lightweight glider, the size and output of the fuel cell can be reduced, along with a lower power motor and reduced hydrogen storage requirement (e.g., NRC, 2013, appendix F). A detailed analysis of this case is outside the scope of this report, but a $20 \%$ weight reduction for the glider could reduce power-train cost by $12 \%$ to $15 \%$ from the values estimated in Table 5 .

Table 5. Estimates of FCV Cost at 200K/yr Production Volume for 2016 and 2020+

\begin{tabular}{lccc}
\hline & & $\begin{array}{c}2020+(200 \mathrm{~K} / \mathrm{yr}) \\
\text { without } \\
\text { breakthrough }\end{array}$ & $\begin{array}{c}2020+(200 \mathrm{~K} / \mathrm{yr}) \\
\text { with technology } \\
\text { breakthrough }\end{array}$ \\
Cost in \$ & $2016(200 \mathrm{~K} / \mathrm{yr})$ & 13,650 & 7,575 \\
Fuel cell stack $(85 \mathrm{~kW})$ & 15,150 & 4,750 & 3,500 \\
Hydrogen storage $(5 \mathrm{~kg})$ & 5,300 & 975 & 975 \\
Battery (35 kW,2 kWh) & 1,300 & 2,825 & 2,400 \\
$\begin{array}{l}\text { Electric Motor/Inverter/Drive } \\
\text { (110 kW peak, 60kW }\end{array}$ & 3,150 & & \\
continuous) & & 350 & 350 \\
Gearbox & 350 & $\mathbf{2 2 , 5 5 0}$ & $\mathbf{1 4 , 8 0 0}$ \\
Total Power-train & $\mathbf{2 5 , 2 5 0}$ & 650 & 650 \\
$\begin{array}{l}\text { Electric HVAC/Regen. Brakes } \\
\text { (incremental) }\end{array}$ & 750 & & \\
Glider (constant weight) & 11,000 & 11,000 & 11,000 \\
Total FCV cost & $\mathbf{3 7 , 0 0 0}$ & $\mathbf{3 3 , 2 0 0}$ & $\mathbf{2 6 , 3 0 0}$ \\
\hline
\end{tabular}




\section{FUTURE GOALS}

In this section the likelihood that cost goals for automotive fuel cells will be met is considered. Past progress in reducing the cost of fuel cell systems has been impressive, as documented in the periodic assessments of high volume (500,000 units/year) manufacturing costs (James, Morton and Colella, 2013; James and Spisak, 2012; James, Kalinoski and Baum, 2010) illustrated in Figure 9. Figure 9 also shows fuel cell system cost projections to 2050 developed by the NRC Committee on Transitions to Alternative Vehicles and Fuels (NRC, 2013). In the NRC Committee's analysis, the mid-range fuel cell system costs, combined with significant load reduction for all vehicle types, enabled eventual dominance of the light duty vehicle market by FCVs without a need for continued subsidies.

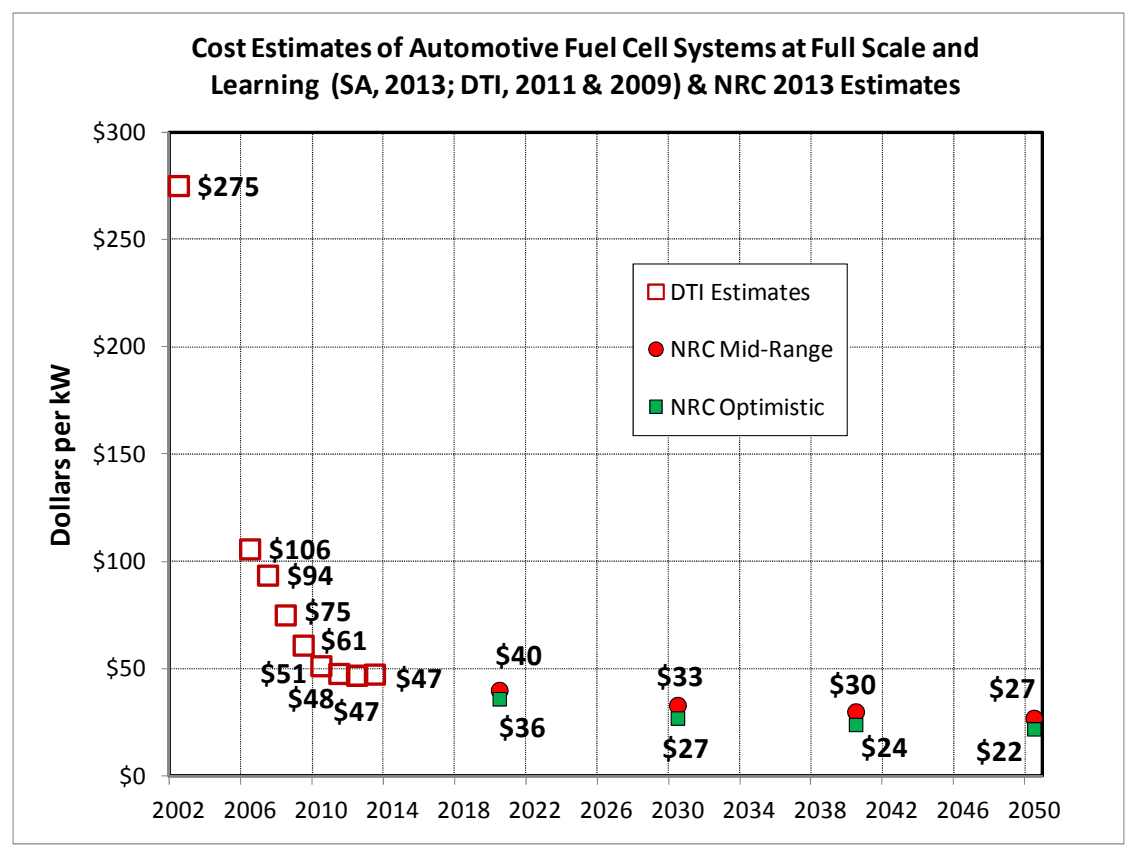

Figure 9. Cost Estimates for Automotive Fuel Cell Systems at Full Scale and Learning. ${ }^{7}$

Two OEMs have provided cost historical, current and future cost estimates as a function of production volumes and time; cumulative production was inferred from these data by linear interpolation of intermediate years. A third OEM provided cost estimates as a function of time, to which volumes consistent with the assumptions of the other OEMs have been added. Given these estimates, the rates of learning and of technological progress that will be necessary to meet the cost projections for the 2020-2022 period can be calculated. An overall scale elasticity of 0.2 is assumed in all cases.

\footnotetext{
${ }^{7}$ Significant changes in assumptions about fuel cell system design by James, Morton and Colella (2013) caused the 2013 estimate to be slightly higher than the 2012 estimate.
} 
In general, the necessary rates of learning and technological progress are reasonable; they are slower than historical rates of progress and plausible in comparison to the range of historical experience for automotive innovations like hybrid electric and battery electric vehicles (e.g., Weiss et al., 2012). The necessary rates of technological progress due to $\mathrm{R} \& \mathrm{D}$ range between $5 \%$ and $8 \%$, while the necessary progress ratios range from 0.96 to 0.94 , implying cost reductions of $4 \%$ to $6 \%$ for each doubling of cumulative production. In all three cases a scale elasticity of -0.2 has been assumed.

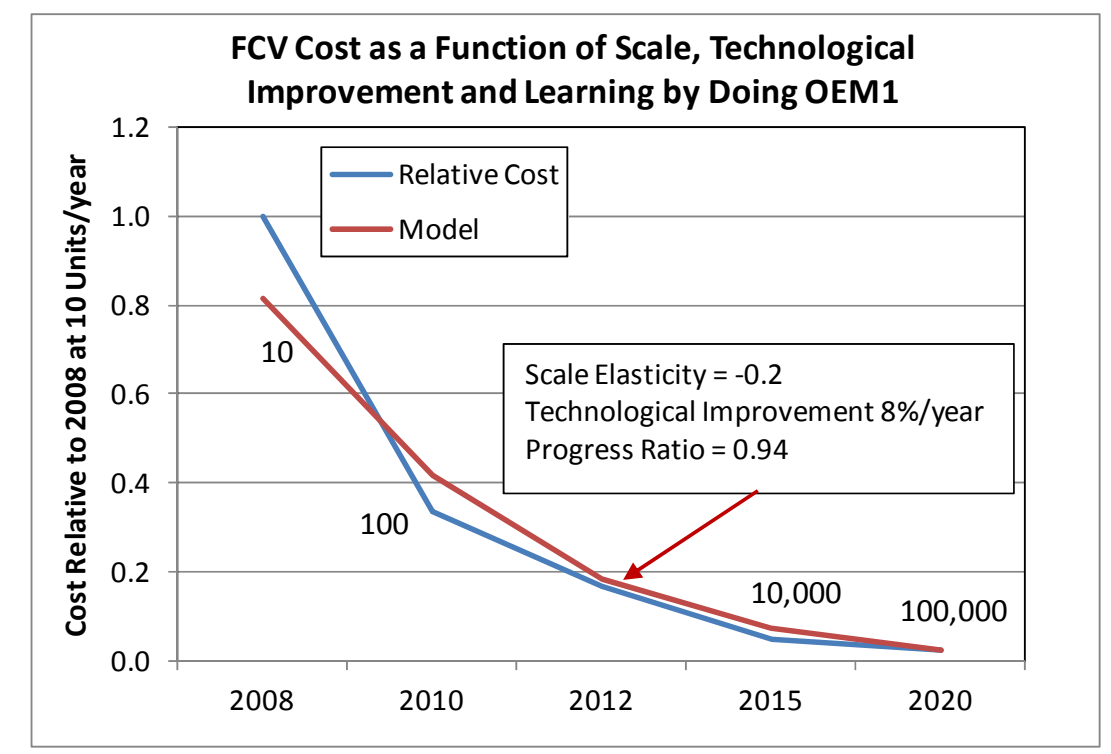

Figure 10. FCV Cost as a Function of Scale, Technological Improvement and Learning by Doing: OEM1. 


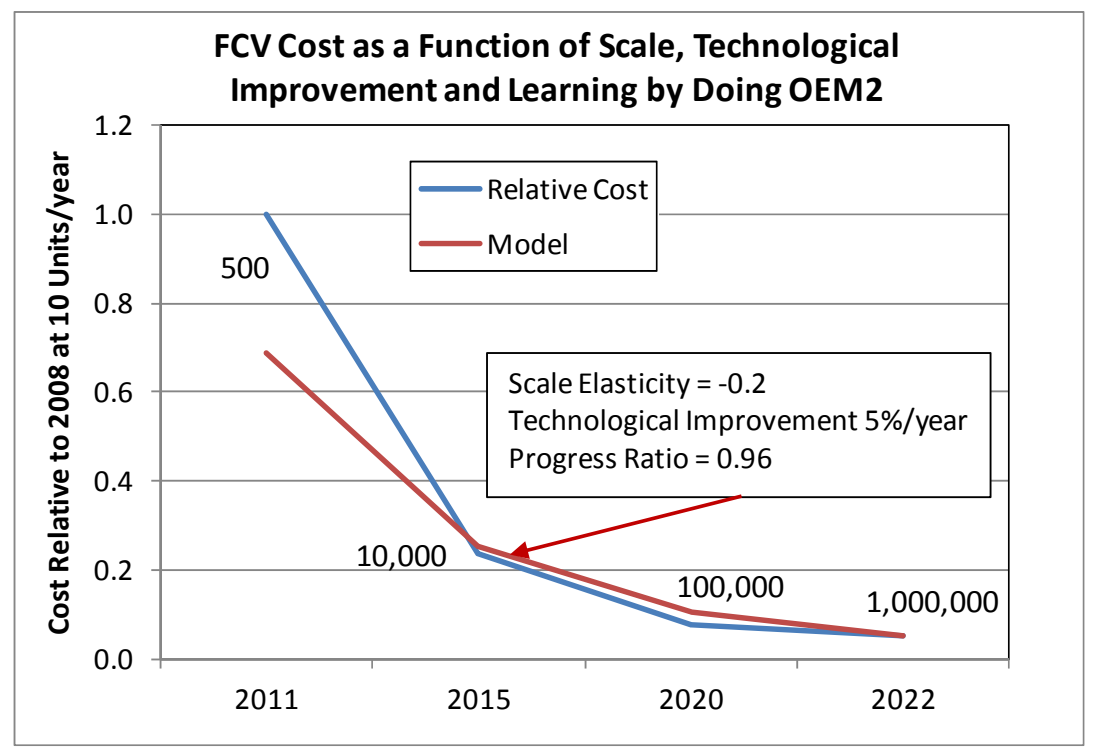

Figure 11. FCV Cost as a Function of Scale, Technological Improvement and Learning by Doing: OEM2.

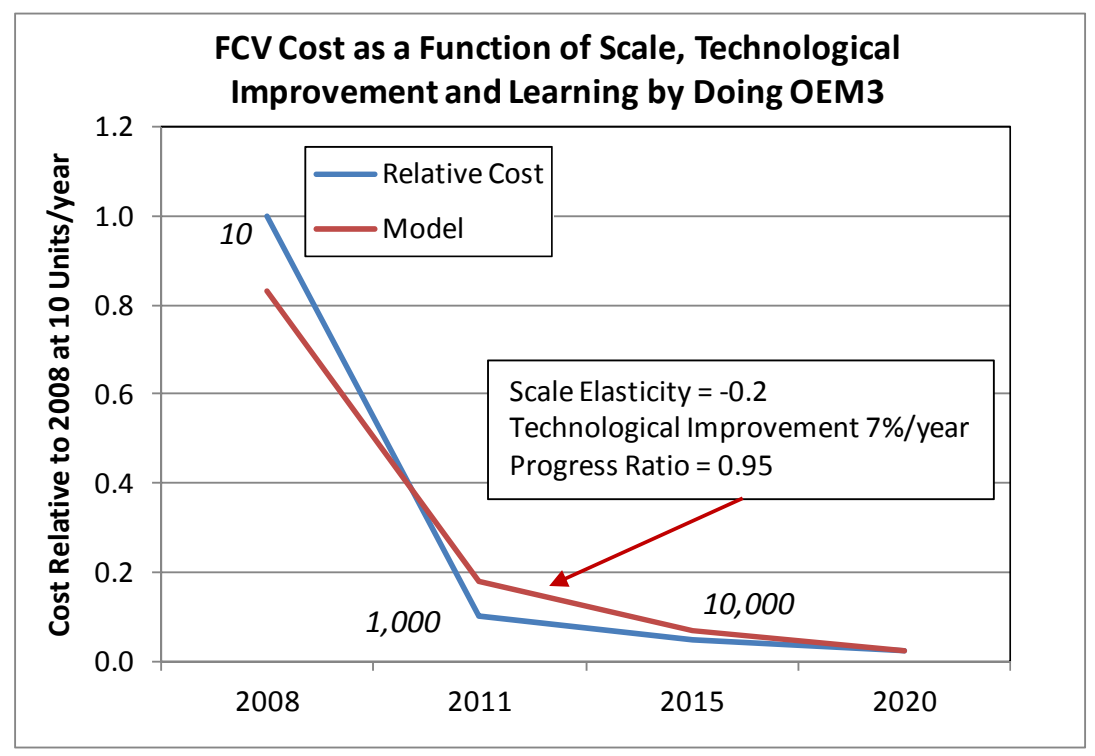

Figure 12. FCV Cost as a Function of Scale, Technological Improvement and Learning by Doing: OEM3. 
These calculations indicate that expectations of competitive costs for FCVs around 2020 are plausible, provided that sufficient production volumes can be achieved. Manufacturers have taken a step towards achieving scale economies by joining together in cooperative agreements, as described above. Success in the marketplace, however, will also depend on consumer acceptance, supporting government policies, and the deployment of adequate hydrogen refueling infrastructure. 


\section{FUEL CELL VEHICLE MARKET INTRODUCTION AND INFRASTRUCTURE DEPLOYMENT PLANS}

California, Germany, Japan, Korea and other countries intending to create markets for FCVs have developed plans for deploying hydrogen refueling infrastructure. At present, the hydrogen stations in operation are few and intended for demonstration purposes but their numbers are increasing. The internet site H2stations.org shows 18 currently operating stations in California, 30 in Germany, 29 in Japan and 12 in South Korea. The website includes mobile stations and stations that are not open to the public but also strives to identify stations that have closed. These numbers are larger than those available for the countries visited late in 2012. Plans for early deployment are in various stages of implementation. In general, both planning and funding is being carried out cooperatively by automotive and energy industries, NGOs and governments. Coordinating station deployments and vehicle sales is a major challenge, made very difficult by the fact that there is at present no profitable business model for early hydrogen stations. Every region is facing major uncertainties about how consumers will respond to HFCVs and limited fuel availability, about the costs and availability of vehicles and hydrogen, about how stations construction and operations will be funded and what other supporting policies may be implemented. Different countries and regions are addressing these challenges in different ways.

\subsection{GERMANY}

In Germany, NOW plays a central role in market creation. NOW is a $100 \%$ government owned organization whose budget is provided by the Federal Ministry of Transport, Building and Urban Development and by the Federal Ministry of Economics and Technology (NOW, 2012). NOW is a member of the H2 Mobility Consortium and of the National Innovation Project (NIP) Hydrogen and Fuel Cell Technology, also key players. The Federal Ministry of Transport supplies 54\% of NOW's total $€ 700$ million multi-year budget for hydrogen and fuel cell projects. The majority of NOW's budget, $€ 500 \mathrm{M}$ goes for demonstration projects designed to prepare the market for hydrogen and fuel cells. Each of their projects is matched with 50\% industry funding on a project-by-project basis. Their portfolio comprises 112 projects, almost all of which are currently running. 2012 was their peak year for expenditures, totaling $€ 260 \mathrm{M}$.

Germany has a detailed plan for the rollout of FCVs and supporting infrastructure: the H2 Mobility Plan. The plan anticipates a self-sustaining FCV business by 2020. Other neighboring countries are also partners in the plan and are coordinating their plans. For example, Switzerland plans to have 10-15 hydrogen refueling stations by 2015. In 2012 there were 150 HFCVs operating in Germany, of which 80 were built by Daimler, 20 by Opel and 8 by Volkswagen (VW). Fifteen hydrogen refueling stations were to be in operation by the end of 2012 (30 are estimated to be operating as of June 2013) and 50 stations are planned to be operating by 2015 . The current stations, by design, take different approaches. Some have liquid delivery to the 
station while others are supplied by trucks carrying compressed gas. All the stations use precooling of hydrogen and deliver the hydrogen at 700 bar or both 700 and 350 bar. Future stations will all be 700 bar capable. All of the initial 50 stations will be add-ons to existing gasoline refueling stations.

The Ministry of Transport has put $€ 40 \mathrm{M}$ in the NIP budget for the initial stations. The stations are expected to cost $€ 2 \mathrm{M}$ each on average, with 50/50 funding by government and industry. The simplest stations will be a hydrogen refueling pump added to an existing petroleum refueling station at a cost of $€ 700,000$ (NOW, 2012). The $€ 40 \mathrm{M}$ should be sufficient to bring the number of stations in Germany to 50 by 2015. Daimler and Linde will build 20 hydrogen refueling stations; others will be built by Air Products, Total and other industry participants. There are plans to put in place another 50 stations in the next few years after 2015 but the intent is to settle on a standardized design to reduce costs. There is a consensus that station operating costs will need to be subsidized for 5-10 years due to anticipated low utilization rates (Butsch, 2012).

The infrastructure rollout will begin with gas truck delivery mostly to small stations of $80 \mathrm{~kg} / \mathrm{d}$ capacity but some will be able to deliver $200 \mathrm{~kg} / \mathrm{d}$. In the future, perhaps by 2025, the plan calls for 1,000 stations with capacities as large as $400 \mathrm{~kg} / \mathrm{d}$ and 1,000 kg/d (NOW, 2012). The retail price of hydrogen to the public is expected to be about $€ 8$ per $\mathrm{kg}$ during the early phases of market development. It is hoped that hydrogen could be sold tax-free for the first five years (to 2020). H2 Mobility participants have agreed to keep the price of hydrogen to the public at least $15 \%$ below the price of gasoline (fully taxed) during this phase.

The $\mathrm{H}_{2}$ Mobility rollout plan for FCVs and hydrogen stations, however, is not likely to evolve according to the original timetable. Given that Hyundai is the only manufacturer planning to produce and sell significant numbers of FCVs prior to 2015, and their plans call for only about 1,000 vehicles, it is highly unlikely that there will be 5,000 fuel cell electric vehicles on Germany's roads in 2015 (Figure 13). NOW is expected to come forward with a revised plan in the near future. The need for a revised plan is understandable since as recently as last year, it was reported that Daimler would begin commercial sales of FCVs in 2014 (Fuel Cell Today, 2012, p. 17), whereas they have more recently indicated that 2017 is more likely, depending on the availability of hydrogen refueling infrastructure. BMW does not plan to introduce FCVs until 2020 or later. 


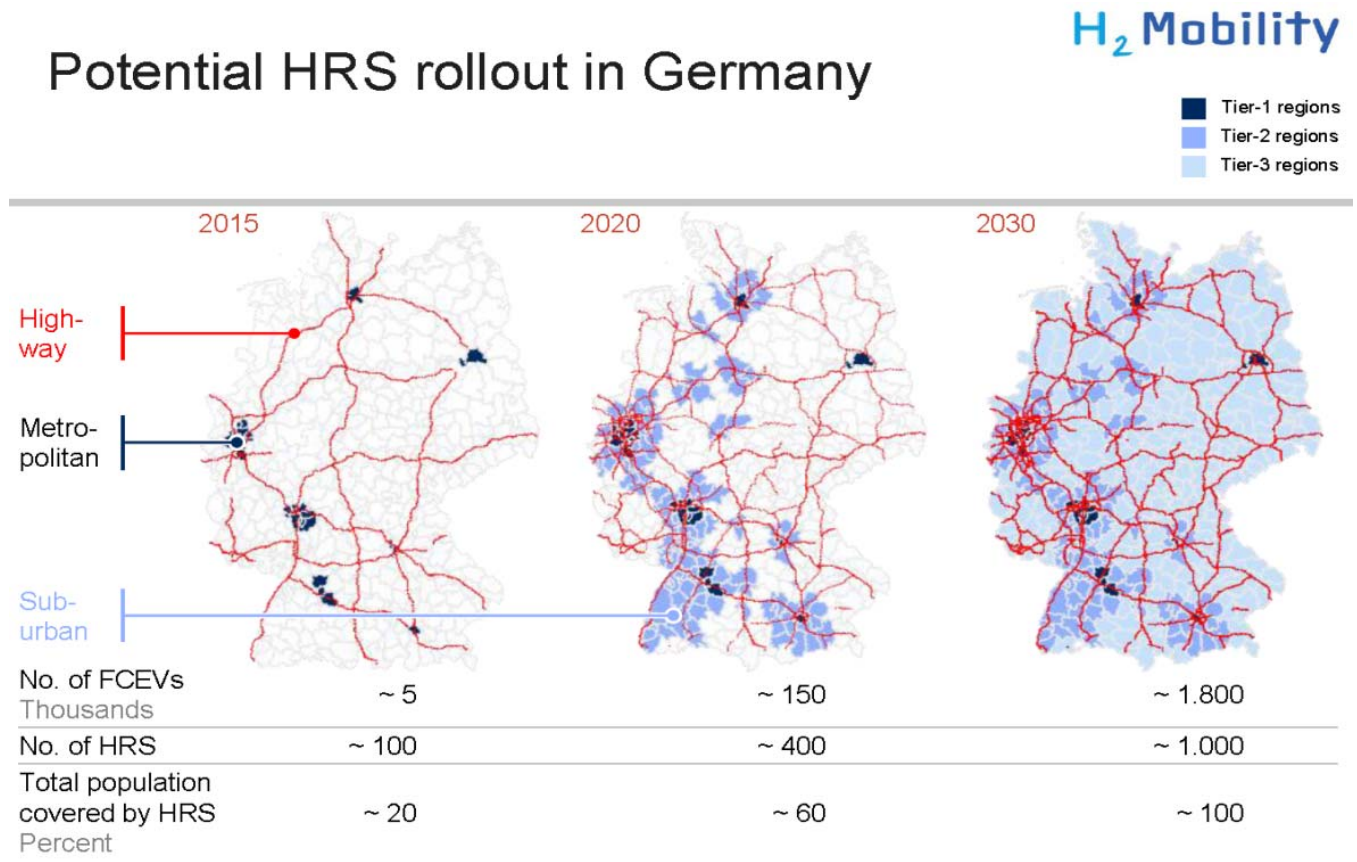

Figure 13. Potential Hydrogen Refueling Station Rollout in Germany (Butsch, 2012).

While the Ministry of Transport is a key supporter of Germany's FCV program, the Ministry of Environment is more doubtful about the prospects for FCVs over the next 10-20 years. The Environment Ministry is unsure that FCVs can be a marketable solution and are doubtful about market acceptance over the next 20 years. They also are not sure that FCVs are needed to meet Germany's climate goals. They see plug-in hybrid electric vehicles (PHEVs) as the main competitors to FCVs in the next two decades. However, PHEVs are not selling well in Germany at present. The plug-in VW Golf costs $€ 8,000$ more than a comparable gasoline version. However, their national plan anticipates that battery costs will come down to one-third of their present level by 2020 (to $€ 250 / \mathrm{kW}$ ). To achieve significant market penetration of plug-in vehicles it will be necessary to get buyers to consider the total cost of ownership. Importantly, two-thirds of the cars sold in Germany are sold as company cars, making the vehicle market very different from that of the United States, for example.

The Environment Ministry also does not expect biofuels to be an important energy source for light-duty vehicles in the future. Rather, biofuels are expected to be used only where other alternatives for reducing greenhouse gas (GHG) emission are lacking, such as for aircraft or heavy-duty vehicles.

There are almost no incentives for purchasing alternative fuel vehicles (AFVs) in Germany. There is only reduction of annual registration fees which are generally less than $€ 100$ /year. The Environment Ministry does not foresee subsidies or mandates for FCVs in the future. If the vehicles come to the market they will be driven by manufacturers' efforts to meet the $\mathrm{EU} \mathrm{CO}_{2}$ 
standards or by taxes on fossil carbon fuels. Many in Germany consider feebates to be an attractive policy but the manufacturers oppose them. Likewise, national government incentives for deployment of electric or hydrogen infrastructure for vehicles are not expected (this would presumably be beyond NOW's funding to deploy 50 stations). However, there are some incentives at the state level, e.g., in Berlin, Stuttgart, Hannover and Munich, to name some areas.

\subsection{JAPAN}

In Japan the Research Association of Hydrogen Supply/Utilization Technology (HySUT) has the responsibility to carry out hydrogen infrastructure demonstration programs for the Fuel Cell Commercialization Conference of Japan (FCCJ). Of the organization’s \$30M budget, \$20M is provided by the New Energy and Industrial Technology Development Organization (NEDO) and \$10M by HySUT, whose members are private corporations. In 2012 HySut was operating 12 demonstration stations. About 60 FCVs were participating in the project, including fuel cell buses. HySUT's demonstration program for the 2012-2015 time frame provides hydrogen free of charge to participating vehicles. This is done to encourage the maximum amount of participation. HySUT is tasked with demonstration programs only; they will not be involved with building or operating commercial stations.

The near-term goal of the FCCJ is to put 100 new publicly accessible, privately owned and operated stations in operation by 2015, when commercial sales of FCVs by OEMs are planned. $\mathrm{H}_{2}$ stations.org currently shows 29 operating hydrogen refueling stations in Japan. They will use a cluster strategy for locating stations, similar to the plans of Germany and California. By 2025, the goal is to have 1,000 stations profitably operating in Japan (there are currently 47,000 refueling stations in Japan). The expectation is that these stations will serve approximately 2 million FCVs. FCVs are expected to consume half as much energy as a comparable hybrid vehicle.

There is agreement that the stations will supply compressed hydrogen gas at 700 bar. Both the energy companies and vehicle manufacturers have agreed on 700 bar as the standard and the government planned to issue standards for $70 \mathrm{MPa}$ refueling in October. This seems to be a decision that has been made and will stand, although it is not clear that all manufacturers believe this is the wisest choice. Only a few demonstration stations are 700 bar currently. They have just started testing $-40^{\circ} \mathrm{C}$ pre-cooling at a few stations. With pre-cooling, refueling requires about three minutes and otherwise it takes over five minutes.

HySUT and FCCJ expect hydrogen to be delivered by compressed gas trucks. Pipelines are not feasible due to current regulatory requirements. There are no regulations that would apply to liquid trucks but it is simply not possible to use them in urban areas (where the stations will be) at the present time because of public concerns about safety. Refineries are the current sources of hydrogen. 
It is not known at present what kind of stations the 100 initial stations will be. Gas companies seem to prefer on-site steam methane reforming (SMR) while the oil companies prefer tube trailer-delivered hydrogen. They have demonstrated a mobile refueling station that carries $30 \mathrm{~kg}$ of hydrogen. They expect the hydrogen to cost $¥ 80 / \mathrm{m}^{3}$, based on a production cost of $¥ 10$ $20 / \mathrm{m}^{3}$ (there are approximately 11 normal cubic meters per kilogram, so $¥ 80 / \mathrm{m}^{3}$ is roughly $\$ 10$ per kg). Hydrogen now costs $¥ 145 / \mathrm{m}^{3}$ and the production cost is $¥ 20 / \mathrm{m}^{3}$. Most of the cost is capital cost for the station: land, compressors, storage. The initial cost is very high. Maintenance of compressors is not yet a big issue.

The FCCJ is planning a budget of $\$ 53$ million to support the construction of the stations. In 2012 there were ongoing negotiations with the Ministry of Economy, Trade and Industry (METI) and the private company members concerning exactly how the plan will be implemented and how costs will be shared. ${ }^{8}$ HySUT expects METI to take responsibility for coordinating the sales of vehicles and establishing the refueling infrastructure. This cannot be done by HySUT or FCCJ due to anti-competitive restrictions.

For its part, METI is confident that Japanese vehicle manufacturers will have vehicles ready for commercialization in 2015. There is no legal commitment by the manufacturers but they have made a commitment to society. The voluntary target of the industry is cumulative sales of two million FCVs by 2025. The New Energy Fundamental Plan for Japan will not include a specific number of vehicles but it will include a forecast of numbers agreed to by the automobile and energy industries and the government. They will hold a conference to discuss the plan and after that will issue expectations for 2030, the target year for the fundamental energy plan.

The 100 station infrastructure plan described above has been authorized by the Japanese government. It is part of Japan’s Green Growth Strategy. For FY 2013 METI was expecting a budget of $¥ 5$ B to subsidize $50 \%$ of the capital costs of constructing the first year’s refueling stations. This does not include land or maintenance costs. The government expects the energy companies to pay the other half of the construction costs. The government will subsidize hydrogen storage tanks at two-thirds, with the companies paying the remaining one-third. Three on-site steam methane reforming stations were built in 2012 that count toward the 100 station total.

The FY 2013 budget is expected to pay for approximately 20 to 25 stations, at a cost of about $¥ 0.5 \mathrm{~B}$ each for on-site steam methane reforming and $¥ 0.4 \mathrm{~B}$ for stations for which the hydrogen is produced off-site and trucked in. The stations are expensive, mainly because of very strict regulations on hydrogen production and storage in residential areas in Japan that are not necessarily designed for a large hydrogen refueling infrastructure. METI expects learning by experience to produce a cost reduction of $15 \%$ per year.

\footnotetext{
${ }^{8}$ We learned from METI that they expect a $¥ 5$ billion budget in 2013 to begin funding $50 \%$ of the capital cost of at least the first several of these 100 stations.
} 
The government expects FCVs to be priced at approximately $¥ 5 \mathrm{M}$ (approximately $\$ 50,000$ ) when they are offered for commercial sale in 2015. FCVs will qualify for a Clean Energy Vehicle Subsidy (BEVs, PHEVs, compressed natural gas vehicles also qualify and the FCV will in 2015). The subsidy will amount to $1 / 2$ of the difference in price from an "ordinary" car. Japan's subsidy to HEVs will end this year. They expect low FCV sales for 10 years, similar to hybrid sales. However, by 2025-30 they expect sales to increase rapidly and the industry to be independent of subsidies.

Part of the challenge faced by FCVs in Japan is a public perception that hydrogen is dangerous. In large part this is a consequence of the Fukushima disaster in which the powerplant explosion was caused by ignition of hydrogen gas.

\subsection{CALIFORNIA}

Most OEMs agreed that at the present time the California Zero Emission Vehicle (ZEV) Standards are the principal source of urgency in HFCV development. While the ZEV standards have been in effect since 1990 and have suffered setbacks and delays over the years, a new set of requirements set to take effect in 2015 is taken very seriously by the OEMs. On March 23, 2012, the Governor of California issued an executive order that set a goal of 1.5 million ZEV on California roadways by 2025 (Office of Governor Edmund G. Brown, 2013). HFCVs are expected to make up a significant fraction of the ZEVs sold in California because they count for seven ZEV credits and because a ZEV sold in California provides ZEV credits in the fourteen other U.S. states that have adopted California's ZEV standards.

The California Fuel Cell Partnership (CAFCP), an NGO made up of government and industry groups, has taken on the responsibility of planning the deployment of early hydrogen refueling infrastructure in California. In January 1999, the California Air Resources Board (ARB) and the California Energy Commission formed a partnership with six automobile manufacturers and energy companies to promote the commercialization of HFCVs in California. Today there are approximately 30 members, including government agencies, OEMs, energy companies and technology companies. Drawing on research and analysis of manufacturers' production plans and the need for refueling infrastructure, the CAFCP published a plan for FCV commercialization (CAFCP, 2012). Based on a confidential survey of vehicle manufacturers, the plan concluded that over 1,000 FCVs would be sold in California in 2014 and that 53,000 would be sold between 2015 and 2017 (Table 6). 
Table 6. CAFCP Estimates of Hydrogen Fuel Cell Vehicle Sales in California Through 2017

\begin{tabular}{cccccc}
\hline Survey Year & 2011 & 2012 & 2013 & 2014 & $2015-2017$ \\
\hline $2010-2011$ & 253 & 312 & 430 & 1389 & 53,000 \\
\hline
\end{tabular}

Based on our discussion with manufacturers, as well as their recent public statements, it seems virtually impossible that the CAFCP's estimated sales would be realized. Indeed, it appears possible but unlikely that as many as 53,000 FCVs will be sold worldwide between 2015 and 2017. The sales projected by the CAFCP are also far in excess of what analysts at the California ARB have estimated would be the minimum requirement to meet the ZEV standards (Table 7). The ARB's estimates of 2,000 to 3,000 vehicles per year, on the other hand, seem to be in line with recent estimates provided by OEMs, though even these estimates are likely to be high for 2015. The rate of sales is significant because it will affect the viability of hydrogen refueling infrastructure whose profitability depends greatly on utilization rates.

Table 7. Comparison of CAFCP Station Deployments and Anticipated FCV Sales with Estimated Minimum ZEV FCV Requirements

\begin{tabular}{|c|c|c|c|c|c|}
\hline \multicolumn{6}{|c|}{ Station Deployment and Expected Vehicle Sales in California } \\
\hline Year & $\begin{array}{l}\text { Start of Year } \\
\text { Station Total }\end{array}$ & $\begin{array}{c}\text { Added } \\
\text { Stations }\end{array}$ & $\begin{array}{c}\text { CAFCP } \\
\text { Number of } \\
\text { Vehicles on } \\
\text { the Road }\end{array}$ & CAFC Sales & $\begin{array}{c}\text { Estimated } \\
\text { Minimum } \\
\text { ZEV Sales } \\
\text { Requirement }\end{array}$ \\
\hline 2012 & 4 & 4 & 312 & 100 & 0 \\
\hline 2013 & 8 & 9 & 430 & 118 & 0 \\
\hline 2014 & 17 & 20 & 1,389 & 959 & 0 \\
\hline 2015 & 37 & 31 & 10,000 & 8,611 & 2,134 \\
\hline 2016 & 68 & Market needs & 20,000 & 10,000 & 2,269 \\
\hline 2017 & 84 & Market needs & 53,000 & 33,000 & 2,297 \\
\hline 2018 & 100 & Market needs & 95,000 & 42,000 & 2,943 \\
\hline
\end{tabular}

Numbers in italics have been approximated based on lower bounds given in CAFCP table 5.

Source: CAFCP (2012), table 5; ICCT estimates.

The CAFCP plan calls for putting 68 public hydrogen refueling stations in operation by 2015. In mid-2012 there were eight hydrogen refueling stations in California that were open to the public (CAFCP, 2013). The stations are to be clustered in three locations in Southern California (Figure 14) and in the San Francisco Bay Area. The CAFCP reports that at present, about half of the stations exist or are in planning or have funding committed, and that another $\$ 65$ million is needed to fully fund the remaining stations. 


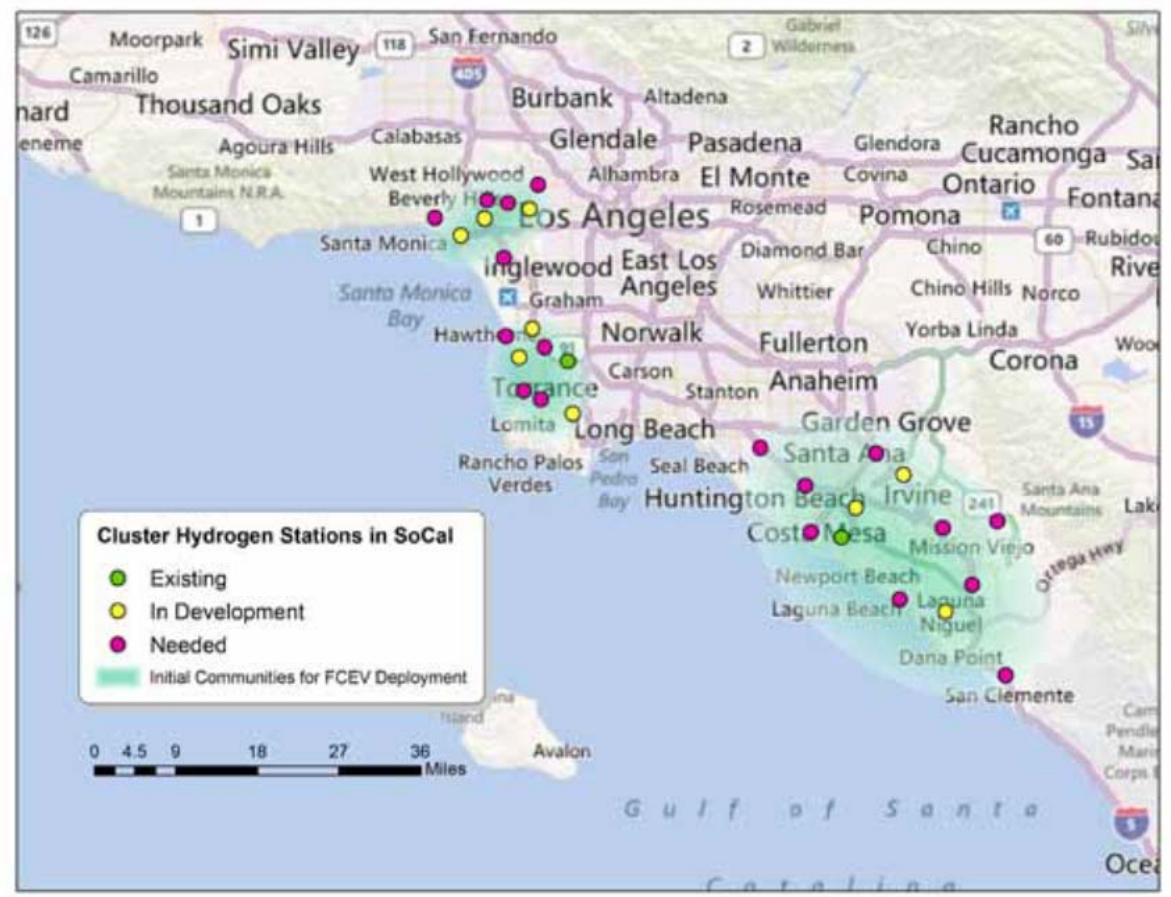

Figure 14. Existing and Planned Clusters of Hydrogen Stations in Southern California.

On May 14, 2013, the U.S. Department of Energy (DOE), vehicle manufacturers, gas suppliers, NGOs and fuel cell manufacturers formed $\mathrm{H}_{2} \mathrm{USA}$, a partnership dedicated to deploying the hydrogen infrastructure necessary to create a market for FCVs. The new organization is expected to play the same role in the United States as $\mathrm{H}_{2}$ Mobility in Germany and $\mathrm{H}_{2} \mathrm{UK}$ in the United Kingdom.

\subsection{DISCUSSION}

Together with the cost of FCVs, availability of hydrogen refueling stations is the OEMs' greatest concern at the present time and will strongly affect their plans for producing FCVs. The planning agencies and OEMs express confidence in the deployment plans that have been developed for all four countries. Yet, when pressed, most admit that there is considerable uncertainty about how much fuel availability will, in fact, be needed to successfully initiate a commercially viable FCV market. Careful analytical studies have been done but there is a inadequate empirical evidence concerning the value of fuel availability to potential FCV purchasers to be confident in the analyses. In addition, in 2012 the funding for the early station deployment had not been fully established, although some commitments had been made and activities were underway to secure the funds needed. Finally, there is uncertainty about whether 
additional stations beyond the initial rollout will require financial support and if so, how that will be provided. 


\section{CONCLUSIONS}

Public and private statements by OEMs and independent evaluations of FCV technology all indicate that FCVs have met the performance benchmarks necessary for sales to the public to begin in 2015, if not sooner. Durability, energy efficiency, cold start, acceleration, refueling, packaging, and range goals have all been met.

OEMs are now focused on cost reduction and the deployment of an adequate refueling infrastructure. Midsize fuel cell passenger cars introduced in 2015-2017 could sell for \$50,000 to $\$ 60,000$, assuming manufacturers did not attempt to recoup full overhead costs. However, further technological progress will be necessary to reduce fuel cell system costs by another $50 \%$, believed to be necessary for a sustainable FCV market. These goals could be achieved by 20202025, assuming plausible scale economies, and rates of learning and technological progress slower than those observed in the recent past. This is not a guarantee of success and substantial uncertainty remains about the ultimate potential of fuel cell and hydrogen storage technology.

Fuel availability is a difficult challenge but is being addressed. Government, industry and NGO groups in all the countries studied have not only formulated plans but have completed demonstrations projects and begun adding stations to supply hydrogen to the public. Yet there are several, critical issues that remain unresolved. It is not clear that currently planned levels of station deployment will be adequate. The transition to a hydrogen vehicle and fuel system is a process with important positive feedbacks and tipping points (NRC, 2013). Too little is known about how potential FCV buyers value fuel availability, as well as how long it will take for vehicle and fuel costs to reach competitive levels. The role that public policy will play in reducing costs to the consumer is another source of uncertainty. Initially, hydrogen retailing will not be profitable and could remain unprofitable for a decade or more. A practical business model for maintaining and expanding hydrogen fuel availability during the transition has yet to be defined. 


\section{REFERENCES}

Butsch, Hanno. 2012. Personal communication and PowerPoint presentation, "Meeting Vorizon,” NOW Headquarters, Berlin, Germany, November 12.

(CAFCP) California Fuel Cell Partnership. 2013. “Stations,” http://cafcp.org/stations .

(CAFCP) California Fuel Cell Partnership. 2012a. A California Road Map: Bringing Hydrogen Fuel Cell Electric Vehicles to the Golden State, available at http://cafcp.org/sites/files/20120814_Roadmapv(Overview).pdf .

(CAFCP) California Fuel Cell Partnership. 2012b. A California Road Map: The Commercialization of Hydrogen Fuel Cell Vehicles, West Sacramento, California, June.

Fuel Cell Today. 2013. Fuel Cell Electric Vehicles: The Road Ahead, Royston, UK, www.fuelcelltoday.com , February.

Fuel Cell Today. 2012. The Fuel Cell Industry Review 2012, Royston, UK, July.

(GM) General Motors. 2013. “GM Investing 200 Million to Expand Powertrain Engineering,” http://media.gm.com/content/media/us/en/gm/news.detail.html/content/Pages/news/us/en/2 013/Jan/0130-powertrain.html, January 30.

Honda. 2013. "Honda FCX Fuel Cell Electric Vehicle Another Step Closer to Market Launch," http://world.honda.com/FuelCell/, May 29.

Hua, T., R. Ahluwalia, J.K. Peng, M. Kromer, S. Lasher, K. McKenney, J. Law and J. Sinha. 2010. Technical Assessment of Compressed Hydrogen Storage Tank Systems for Automotive Applications, ANL-10/24, Argonne National Laboratory, Argonne, Illinois, September.

Hyundai. 2013. “Hyundai IX35 Fuel Cell,” http://www.hyundainews.com/us/enus/Media/PressRelease.aspx?mediaid=38232, Hyundai Motor America, Costa Mesa, California, March 5.

James, B.D. and A.B. Spisak. 2012. "Mass Production Cost Estimation of Direct $\mathrm{H}_{2}$ PEM Fuel Cell Systems for Transportation Applications: 2012 Update,” Strategic Analysis, Arlington, Virginia, October 18.

James, B.D., J.M. Moton and W.G. Colella. 2013. "Fuel Cell Transportation Cost Analysis," U.S. Department of Energy 2013 Annual Merit Review and Peer Evaluation Meeting for the Hydrogen and Fuel Cell Technologies Program, Arlington, Virginia, May 14. 
James, B.D., J.A. Kalinoski and K.N. Baum. 2010. "Mass Production Cost Estimation for Direct $\mathrm{H}_{2}$ PEM Fuel Cell Systems for Automotive Applications: 2010 Update,” Directed Technologies, Inc., Arlington, Virginia, September 30.

McKinsey \& Co. 2011. A Portfolio of Powertrains for Europe: A Fact-Based Analysis, sponsored in part by National Organisation Wasserstoff, Berlin, available on the internet at http://ec.europa.eu/research/fch/pdf/a_portfolio_of_power_trains_for_europe_a_fact_based _analysis.pdf.

Nelson, G. 2013. "Hyundai, Mercedes, Nissan, Toyota join DOE in Fuel Cells Push," Automotive News, http://www.autonews.com/article/20130513/OEM05/130519963\#axzz2UgzoQNRV, May 13.

(NOW) National Organisation Wasserstoff. 2012. NOW Annual Report 2012, Berlin, Germany.

(NRC) National Research Council. 2013. Transitions to Alternative Vehicles and Fuels, Appendix F, "Vehicles,” National Academies Press, Washington, DC.

Office of Governor Edmund G. Brown. 2013. 2013 ZEV Action Plan, Governor's Interagency Working Group on Zero-emission Vehicles, Sacramento, California, http://opr.ca.gov/docs/Governor's_Office_ZEV_Action_Plan_(02-13).pdf .

(WSJ) Wall Street Journal. 2013. "UPDATE: Toyota, BMW Expand Technology-Sharing Partnership for fuel Cell, Other Vehicles,” http://online.wsj.com/article/BT-CO-20130124704894.html, January 24.

Weiss, M., M.K. Patel, M. Junginger, A. Perujo, P. Bonnel and G. van Grootveld. 2012. “On the Electrification of Road Transport - Learning Rates and Price Forecasts for Hybrid-Electric and Battery Electric Vehicles," Energy Policy, http://dx.doi.org/10.0116/j.enpol.2012.05.038.

Wipke, K., S. Sprik, J. Kurtz, T. Ramsden, C. Ainscough and G. Saur. 2012. National Fuel Cell Electric Learning Demonstration Final Report, NREL/TP-5600-54860, National Renewable Energy Laboratory, Golden, Colorado, July.

www.media.blog. 2012. "The Strategic Cooperation Between Daimler and the Renault-Nissan Alliance Forms Agreement with Ford to Accelerate Commercialization of Fuel Cell Electric Vehicle Technology,” http://www.media.blog.alliance-renaultnissan.com/news/the-strategic-cooperation-between-daimler-and-the-renault-nissanalliance-forms-agreement-with-ford-to-accelerate-commercialization-of-fuel-cell-electricvehicle-technology-2/. 